\title{
Aspergillus: A Powerful Protein Production Platform
}

\author{
Fani Ntana ${ }^{1} \mathbb{0}$, Uffe Hasbro Mortensen ${ }^{2}$, Catherine Sarazin ${ }^{1, *}$ and Rainer Figge ${ }^{1}$ \\ 1 Unité de Génie Enzymatique et Cellulaire, UMR 7025 CNRS/UPJV/UTC, Université de Picardie Jules Verne, \\ 80039 Amiens, France; fani.ntana@u-picardie.fr (F.N.); rainer.figge@u-picardie.fr (R.F.) \\ 2 Department of Biotechnology and Biomedicine, Technical University of Denmark, Søltofts Plads, \\ Building 223, 2800 Kongens Lyngby, Denmark; um@bio.dtu.dk \\ * Correspondence: catherine.sarazin@u-picardie.fr; Tel.: +33-3-22-82-75-95
}

Received: 29 August 2020; Accepted: 11 September 2020; Published: 16 September 2020

\begin{abstract}
Aspergilli have been widely used in the production of organic acids, enzymes, and secondary metabolites for almost a century. Today, several GRAS (generally recognized as safe) Aspergillus species hold a central role in the field of industrial biotechnology with multiple profitable applications. Since the 1990s, research has focused on the use of Aspergillus species in the development of cell factories for the production of recombinant proteins mainly due to their natively high secretion capacity. Advances in the Aspergillus-specific molecular toolkit and combination of several engineering strategies (e.g., protease-deficient strains and fusions to carrier proteins) resulted in strains able to generate high titers of recombinant fungal proteins. However, the production of non-fungal proteins appears to still be inefficient due to bottlenecks in fungal expression and secretion machinery. After a brief overview of the different heterologous expression systems currently available, this review focuses on the filamentous fungi belonging to the genus Aspergillus and their use in recombinant protein production. We describe key steps in protein synthesis and secretion that may limit production efficiency in Aspergillus systems and present genetic engineering approaches and bioprocessing strategies that have been adopted in order to improve recombinant protein titers and expand the potential of Aspergilli as competitive production platforms.
\end{abstract}

Keywords: Aspergillus; fermentation; filamentous fungi; genetic engineering; heterologous expression; recombinant protein; secretion; transcriptional regulation

\section{Introduction}

Proteins are functionally versatile biomolecules (e.g., enzymes, structural proteins, and hormones) involved in multiple biological processes in the cell. Despite their role in supporting biological systems, proteins have been extensively studied for their potential in the formulation of commercial products. They often find applicability in the production of pharmaceuticals, food, beverages, biofuels, cosmetics, detergents, etc. [1,2].

Market demand for industrially relevant proteins has guided research into exploring practices that can lead to large-scale production levels [3]. The development of recombinant DNA technology has opened up the possibility of producing recombinant proteins in heterologous expression systems that can support high production yields. In that respect, any gene can now be transferred into a production host able to generate large quantities of the corresponding protein of interest, avoiding limitations related to the conventional extraction of the protein from its native host [4]. Human insulin produced in E. coli cells was the first recombinant protein that was actually approved by the FDA for clinical use. The recombinant insulin Humulin ${ }^{\circledR}$, originally developed by Genentech, was eventually commercialized in 1982 [3]. Since then, a plethora of other proteins with pharmaceutical and industrial applications have successfully been synthesized in heterologous expression systems and have made their way into the market [1]. 
Today, recombinant proteins can be synthesized using a wide range of production platforms, including bacteria, yeasts and filamentous fungi, mammalian or insect cells, and transgenic plants, to name a few. Every heterologous production system though comes with certain advantages and drawbacks (Table 1). In most cases, the structure and function of the protein of interest determines which production system is the most appropriate to be used. For example, when it comes to manufacturing therapeutic proteins of high quality, mammalian cell lines are predominantly used, as they can produce complex, human-like glycosylated proteins that are safe for patients. In fact, almost $84 \%$ of the biopharmaceutical proteins are currently produced by Chinese Hamster Ovarian (CHO) cell lines [5].

For the production of non-medicinal proteins, a more economical approach is usually followed, using either bacterial or fungal production hosts $[1,6,7]$. While bacteria are often suitable for smaller proteins that do not require complex post-translational modifications, production of larger and more complex proteins is usually performed in yeast, e.g., Pichia pastoris [8]. However, yeasts have the tendency to hyperglycosylate secreted proteins, and thus reduce their in vivo half-life and affect their efficacy [9]. Additional limitations including low expression levels and plasmid instability have restricted the use of some yeasts (e.g., S. cerevisiae) in the production of industrial enzymes [10]. An alternative production platform that can support low-cost synthesis of large proteins with complex modifications, but with a lesser degree of hypermannosylation during glycosylation compared to yeast is filamentous fungi. In addition, due to their saprophytic lifestyle, most filamentous fungi have already developed the ability to produce and secrete a vast amount of enzymes in order to break down and feed on organic matter [11]. Strains belonging to the genera Aspergillus, Trichoderma, and Neurospora are in fact widely used for production of recombinant proteins with industrial applications [12-15]. Several reviews have described the potentials of filamentous fungi in the production of pharmaceutical and other industrial proteins, as well as the genetic engineering approaches followed to maximize production levels $[7,16,17]$. In this review, we specifically focus on the use of Aspergillus species in the manufacturing of recombinant proteins. Bottlenecks in protein synthesis and secretion are discussed, while our comprehensive literature search provides a general overview of the most important genetic engineering projects and bioprocessing strategies applied over the past 30 years to improve recombinant protein yields in Aspergillus. 
Table 1. Comparison of the most commonly used heterologous expression systems in the field of recombinant protein production.

\begin{tabular}{|c|c|c|c|c|c|c|c|c|}
\hline $\begin{array}{l}\text { Expression } \\
\text { Platform }\end{array}$ & $\begin{array}{c}\text { Genetic } \\
\text { Manipulation }\end{array}$ & Growth Rate & Product Titers & Product Quality & $\begin{array}{c}\text { Product } \\
\text { Purification }\end{array}$ & $\begin{array}{c}\text { Contamination } \\
\text { Risk }\end{array}$ & $\begin{array}{l}\text { Production } \\
\text { Cost }\end{array}$ & $\begin{array}{c}\text { Relevant } \\
\text { Literature }\end{array}$ \\
\hline $\begin{array}{c}\text { Bacteria } \\
\text { (Escherichia coli) }\end{array}$ & Simple & Fast & High & $\begin{array}{l}\text { Products can be } \\
\text { non-functional (codon } \\
\text { bias, no adequate } \\
\text { post-translation } \\
\text { modifications) }\end{array}$ & $\begin{array}{l}\text { Can be } \\
\text { problematic } \\
\text { (e.g., inclusion } \\
\text { bodies) }\end{array}$ & $\begin{array}{l}\text { Medium } \\
\text { (endotoxins) }\end{array}$ & Low & {$[18,19]$} \\
\hline $\begin{array}{c}\text { Yeasts } \\
\text { (Saccharomyces } \\
\text { cerevisiae, Pichia } \\
\text { pastoris, etc.) }\end{array}$ & Simple & Fast & $\begin{array}{l}\text { S. cerevisiae } \\
\text { limited } \\
\text { P. pastoris higher }\end{array}$ & $\begin{array}{l}\text { Hypermannosylation of } \\
\text { glycoproteins often } \\
\text { occurs (shortens half-life } \\
\text { of the protein in vivo, } \\
\text { leads to immunogenic } \\
\text { reactions) }\end{array}$ & Feasible & Low & Low & {$[9,10]$} \\
\hline $\begin{array}{l}\text { Filamentous fungi } \\
\text { (Aspergillus niger, } \\
\text { Trichoderma reesei, } \\
\text { Neurospora crassa) }\end{array}$ & Feasible & Medium & High & $\begin{array}{l}\text { Less hypermannosylation } \\
\text { compared to yeasts, but } \\
\text { still differences from } \\
\text { mammalian } \\
\text { glycosylation patterns }\end{array}$ & Simple & $\underset{\text { (mycotoxins) }}{\text { Medium }}$ & Low & [7] \\
\hline $\begin{array}{l}\text { Insect cells } \\
\text { (Spodoptera } \\
\text { frugiperda, } \\
\text { Drosophila } \\
\text { melanogaster) }\end{array}$ & Laborious & Fast & High & $\begin{array}{l}\text { Not able to carry out } \\
N \text {-glycosylation }\end{array}$ & Feasible & Very low & High & [20] \\
\hline $\begin{array}{l}\text { Mammalian cells } \\
\text { (CHO cells, Human } \\
\text { cell lines) }\end{array}$ & Laborious & Slow & Low & $\begin{array}{l}\text { High quality therapeutic } \\
\text { proteins, human-like } \\
\text { glycosylation pattern }\end{array}$ & Simple & $\begin{array}{l}\text { High (viruses } \\
\text { and prions) }\end{array}$ & High & [21] \\
\hline $\begin{array}{l}\text { Transgenic animals } \\
\text { (goats, chickens) }\end{array}$ & Laborious & Very slow & High & $\begin{array}{c}\text { High quality } \\
\text { therapeutic proteins }\end{array}$ & Simple & $\begin{array}{l}\text { High (viruses } \\
\text { and prions) }\end{array}$ & $\begin{array}{c}\text { High, ethically } \\
\text { questionable }\end{array}$ & [22] \\
\hline $\begin{array}{l}\text { Transgenic plants } \\
\text { (rice, bananas, } \\
\text { carrots, potatoes) }\end{array}$ & Feasible & Slow & High & $\begin{array}{l}\text { Some differences in } \\
\text { glycan structures from } \\
\text { human-like pattern }\end{array}$ & $\begin{array}{l}\text { Complex and } \\
\text { expensive } \\
\text { downstream } \\
\text { processing }\end{array}$ & Very low & Medium & {$[23,24]$} \\
\hline
\end{tabular}




\section{Industrial Application of Aspergilli}

\subsection{Traditional Uses of Aspergillus Species}

The use of Aspergillus species in biotechnology begun approximately a century ago, when James Currie, a food chemist, discovered that the filamentous mold A. niger was able to produce citric acid, a food and beverage additive that was conventionally extracted from citrus fruits [25]. Since then, production of citric acid, now performed in $A$. niger cultures that grow on inexpensive sugar-based minimal media, has turned into a multibillion dollar business [26].

Nonetheless, industrial applications of Aspergilli are not limited to the production of citric acid. Several species have been used as prolific producers of other organic acids (e.g., itaconic), secondary metabolites, and enzymes of biotechnological significance [11]. For example, A. niger produces several enzymes used in food and feed production such as glucoamylases, proteases, and phytases [26]. A. oryzae, traditionally used in Asian cuisine, has been exploited as a cell factory for producing malate, which is used in the development of food and pharmaceutical products [27]. A. terreus has attracted interest due to its ability to produce a group of secondary metabolites called statins that are used in the production of cholesterol-lowering drugs [28]. In fact, AB Enzymes, BASF, Chr. Hansen, DuPont, and Novozymes are only a few examples of companies that have been or are still using Aspergillus species in large-scale manufacturing of commercial products such as organic acids, enzymes, proteins, and secondary metabolites [29].

\subsection{The Use of Aspergillus Species in Heterologous Protein Production}

Filamentous fungi are generally considered promising hosts for production of recombinant proteins, mainly due to their secretory capacity and metabolic versatility. However, only a few species appear to be able to produce competitive recombinant protein levels and even fewer have been developed into industrial production platforms. This can be attributed mainly to our incomplete knowledge of fungal physiology. For example, the mechanisms behind protein production and secretion in fungal cells are not yet fully understood for most of the species. In addition, the presence of unwanted metabolites (e.g., mycotoxins) has excluded several fungi from industrial production [29].

Aspergillus is a genus that has been studied extensively due to its value as a model organism in fungal research (A. nidulans) and its industrial importance in citric acid and enzyme production (A. niger, A. oryzae) [26]. Several molecular tools (e.g., synthetic promoters and terminators, selection markers, RNA interference-RNAi, and CRISPR-Clusters of Regularly Interspaced Short Palindromic Repeats-associated technologies), suitable for Aspergillus species, have also been developed, facilitating efficient and targeted manipulation of their genomes [30,31]. CRISPR/Cas, for example, a system developed to create site-specific double strand DNA breaks, has been successfully applied in editing the genome of A. niger [32-35], A. nidulans [35], A. oryzae [36], A. fumigatus [37], and other aspergilli [35]. With a relatively well-understood physiology (growth and development, gene expression, and secretion machinery) and several molecular tools available, the GRAS A. niger has already been used in industrial production of recombinant proteins, such as calf chymosin [38], human lactoferrin [39], and the plant-derived sweetener neoculin [40]. Nevertheless, heterologous protein production in Aspergillus species is not always efficient, leading to low production titers. In such cases, strategies that are usually applied to improve titers involve genetic engineering of the production strains and establishing the appropriate fermentation conditions.

\section{Genetic Engineering Approaches for Aspergillus Strain Improvement}

Due to their capacity to secrete large quantities of proteins into the culture medium, Aspergillus species, and especially A. niger, are considered promising candidates for the development of large-scale heterologous protein production platforms. However, production yields for heterologous proteins are usually much lower compared to the ones detected for the native proteins. Failure to achieve the desired protein amounts in Aspergillus cultures can be attributed to limitations related to 
transcription, translation, and the post-translation processing and modifications during protein production. Additionally, bottlenecks in the fungal secretion machinery and the problem of extracellular degradation by fungal proteases further hinder the efficient production of foreign proteins in Aspergillus species [41]. These limitations during protein production in aspergilli will be discussed in detail in the following paragraphs.

\subsection{Transcriptional Regulation}

\subsubsection{Promoters}

Regulation of protein synthesis begins on the level of transcription. The first step for achieving high protein yields in heterologous production systems is the use of strong promoters that can drive high gene expression. A variety of constitutively active (e.g., PgpdA, glyceraldehyde-3-phosphate dehydrogenase promoter; PadhA, aldehyde dehydrogenase promoter; Ptef1, translation elongation factor 1 promoter; and $\mathrm{Ph} 4 \mathrm{~h} 3$, histones $\mathrm{H} 4.1$ and $\mathrm{H} 3$ bidirectional promoter) and inducible promoters (e.g., PglaA, glucoamylase promoter; PalcC, alcohol dehydrogenase promoter; and PamyA, amylase promoter) are currently available for Aspergillus species [42,43].

Native inducible promoters are commonly used as being more efficient in achieving high protein titers, as they allow separation of protein synthesis from biomass formation. This separation can also be extremely useful when the protein to be produced is toxic for the fungus [42]. The inducible promoter of the A. niger glucoamylase gene (PglaA) is frequently used in many Aspergillus expression systems. Expression of gla $\mathrm{A}$ is highly induced when maltose or starch are used as carbon sources, but repressed in the presence of xylose. High glaA expression levels have been correlated with a $5^{\prime}$ cis-regulatory element, and specifically the region within $500 \mathrm{bp}$ upstream of the translational start codon. This region ( -464 to -426$)$ contains a protein-binding CCAAT motif, crucial for the high activity of PglaA [44]. Insertion of eight copies of this region into the PglaA sequence significantly increased expression levels of a heterologous gene (Vitreoscilla haemoglobin), multiplying protein production by almost 20-fold [45] (Table 2).

Table 2. Approaches for improving recombinant protein production through promoter engineering.

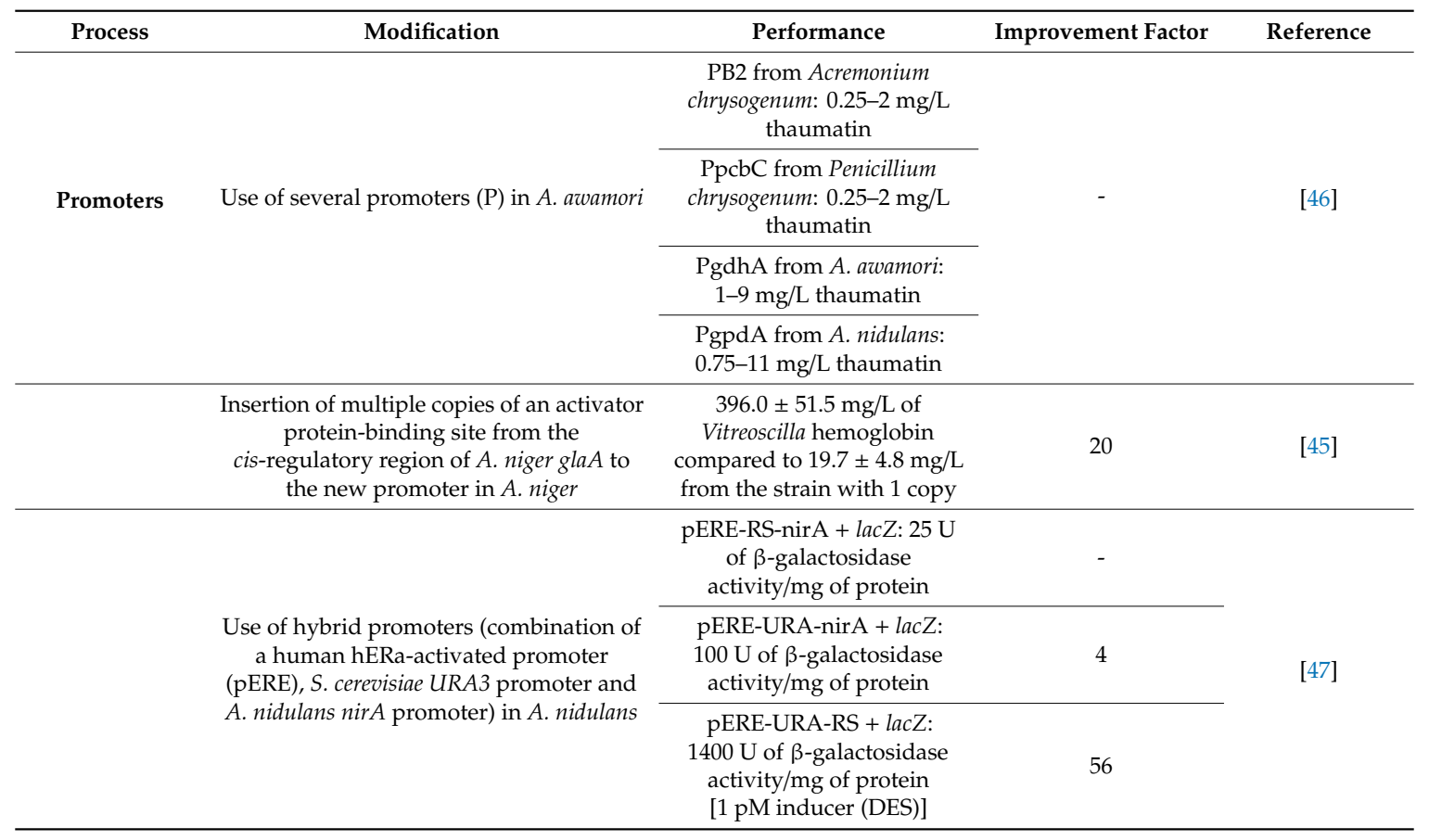


Table 2. Cont.

\begin{tabular}{|c|c|c|c|c|c|}
\hline Process & \multicolumn{2}{|c|}{ Modification } & Performance & Improvement Factor & Reference \\
\hline & \multirow{3}{*}{\multicolumn{2}{|c|}{$\begin{array}{l}\text { Use of a hemolysin-like protein promoter } \\
\text { (Phyl) for heterologous production in } \\
\text { A. oryzae }\end{array}$}} & $\begin{array}{c}\text { Reporter gene: } \\
\text { Endoglucanase Cel B } \\
\text { Pamy: } 24.1 \pm 5.5 \mathrm{U} / \mathrm{mL}, \text { Phyl: } \\
57.9 \pm 17.4 \mathrm{U} / \mathrm{mL}\end{array}$ & 2.4 & \multirow{3}{*}{ [48] } \\
\hline & & & $\begin{array}{l}\text { Reporter gene: Trichoderma } \\
\text { endoglucanase I } \\
\text { Pamy: } 7.7 \pm 3.9 \mathrm{U} / \mathrm{mL}, \text { Phyl: } \\
27.8 \pm 1.3 \mathrm{U} / \mathrm{mL}\end{array}$ & 3.6 & \\
\hline & & & $\begin{array}{c}\text { Reporter gene: Trichoderma } \\
\text { endoglucanase III } \\
\text { Pamy:4.0 } \pm 0.6 \mathrm{U} / \mathrm{mL} \\
\text { hyl: } 31.7 \pm 3.3 \mathrm{U} / \mathrm{mL}\end{array}$ & 7.9 & \\
\hline & \multirow{3}{*}{\multicolumn{2}{|c|}{$\begin{array}{l}\text { Regulatory elements (TerR and PterA) } \\
\text { from } A \text {. terreus terrain gene cluster for } \\
\text { E. coli lacZ expression in } A \text {. niger }\end{array}$}} & $\begin{array}{c}\text { Promoter activity } \\
\sim 5000 \mathrm{mU} / \mathrm{mg} \text { when TerR } \\
\text { under PgpdA (No activity } \\
\text { when TerR under the } \\
\text { native promoter) }\end{array}$ & - & \multirow{3}{*}{ [49] } \\
\hline & & & $\begin{array}{l}\text { Promoter activity } \sim 10,000 \\
\mathrm{mU} / \mathrm{mg} \text { (when TerR under } \\
\text { PgpdA in } 2 \text { copies) }\end{array}$ & 2 & \\
\hline & & & $\begin{array}{l}\text { Promoter activity } \\
\sim 15,000 \mathrm{mU} / \mathrm{mg} \text { (when TerR } \\
\text { under PamyB) }\end{array}$ & 3 & \\
\hline & \multicolumn{2}{|c|}{$\begin{array}{c}\text { A. niger } \alpha \text {-glucosyltransferase produced } \\
\text { under the A. niger pyruvate } \\
\text { kinase promoter }\end{array}$} & $\begin{array}{l}2000 \mathrm{U} / \mathrm{mL} \text { total activity of } \\
\alpha \text {-glucosyltransferase } \\
\text { compared to } 600 \mathrm{U} / \mathrm{mL} \text { in } \\
\text { the wild type }\end{array}$ & 3.3 & [50] \\
\hline & \multicolumn{2}{|c|}{$\begin{array}{l}\text { Overexpression of the transcription factor } \\
\text { RsmA, while the aflR promoter was } \\
\text { inserted in front of the pslcc in } A \text {. nidulans }\end{array}$} & $\begin{array}{l}0.06 \mathrm{U} / \mathrm{mL} \text { of Pycnoporus } \\
\text { sanguineus laccase compared } \\
\text { to } 0.004 \mathrm{U} / \mathrm{mL} \text { in the } \\
\text { control strain }\end{array}$ & 15 & {$[51,52]$} \\
\hline & \multirow{3}{*}{$\begin{array}{c}\text { The } \\
\text { constitutive } \\
\text { promoter of } \\
\text { ecm33 (Pecm 33) } \\
\text { from A. niger in } \\
\text { A. niger }\end{array}$} & Maltose: & $\begin{array}{l}\text { Pecm } 33 \text { activity induced by } \\
1.7 \text { compared to PglaA } \\
\text { activity that induced by } 2.7\end{array}$ & \multirow{3}{*}{-} & \multirow{3}{*}{ [54] } \\
\hline & & Glucose: & $\begin{array}{l}\text { Pecm33 activity induced by } \\
1.1 \text { compared to PglaA } \\
\text { activity that induced by } 1.8\end{array}$ & & \\
\hline & & Xylose: & $\begin{array}{l}\text { Pecm33 activity induced by } \\
2 \text { compared to PglaA activity } \\
\text { that induced by } 1.3 \\
\text { Increased Pecm } 33 \text { activity at } \\
37^{\circ} \mathrm{C}\end{array}$ & & \\
\hline
\end{tabular}

Although the majority of the promoters used are derived from the primary metabolism, there have also been attempts to develop expression cassettes using regulatory elements from fungal secondary metabolite pathways (Table 2) [49,51,52]. In such cases, the strain carries the heterologous gene under the control of an inducible promoter and it is engineered to overexpress the gene that encodes the transcription factor, which activates the specific promoter, thus achieving high expression levels.

Apart from the endogenous promoters discussed above, non-endogenous, or synthetic, tunable promoter systems have also been developed for Aspergillus species [47,55-57]. One of them, the Tet On/Off system, was adapted from the mechanism regulating the tetracycline resistance operon in E. coli. It is also based on a dual player system, where the production strain is co-transformed with a plasmid carrying the heterologous gene regulated by the activity of a tetracycline-responsive promoter and a plasmid encoding a tetracycline transactivator (tTA). In the absence of the tetracycline or its derivative, doxycycline (DOX), the tTA binds to the promoter, inducing heterologous gene expression. However, where DOX is added, tTA disassociates from the binding sites and expression shuts down [56]. 


\subsubsection{Gene Copy Number and Integration Site}

In general, it has been suggested that integration of multiple gene copies can result in increased protein production levels. This has been observed frequently in Aspergillus systems expressing native proteins, such as glucoamylase or amylase (Table 3) [58-60]. In fact, A. niger strains containing multiple glaA copies (20 and 80 ) were able to secrete five to eight times more glucoamylase [59]. Similarly, introducing additional copies of heterologous genes also leads to higher amounts of protein produced (Table 3) $[47,61]$. However, this is not always the case. While studying the effect of copy number on heterologous expression in A. nidulans, Lubertozzi and Keasling (2006) observed that $\beta$-galactosidase activity of the transformants did not consistently correlate with the lac $Z$ dosage. They suggested that this could be due to a gene silencing mechanism, previously observed in filamentous fungi, or due to pleiotropic effects of random integration [62]. In addition, Verdoes et al. (1995) suggests that the reasons for this limitation in protein production by strains harboring multiple copies is both the site of integration and the availability of trans-regulatory factors involved in transcription [63].

Table 3. Approaches for improving recombinant protein production through integration of multiple gene copies.

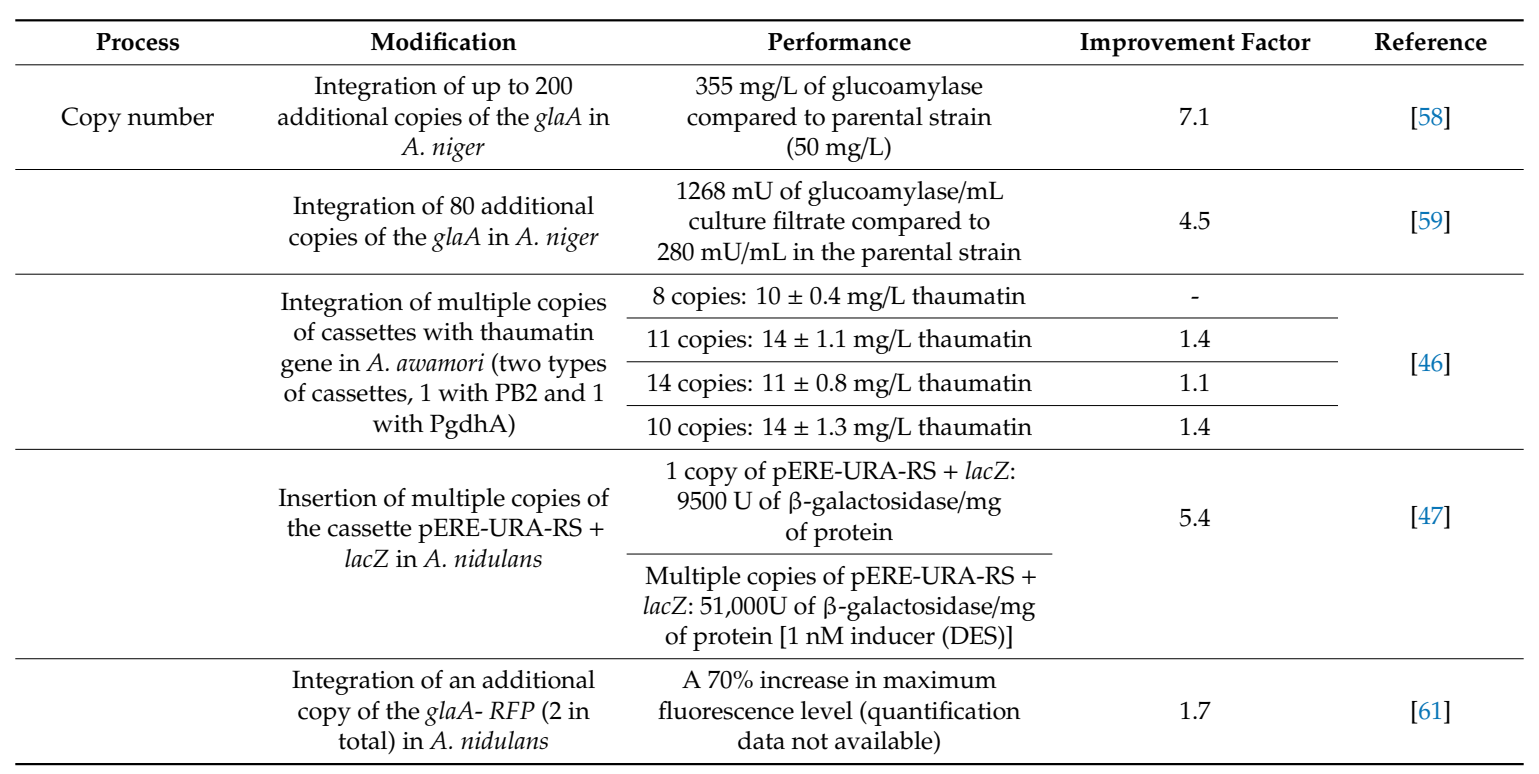

The genomic site, where the expression cassette is integrated during transformation, is indeed an important factor that influences transcription of the heterologous gene and consequently protein production $[62,63]$. In order to tackle unpredicted limitations related to random insertion, site-specific integration systems are usually applied [32,64]. Moreover, identification of genomic loci with high transcriptional activity, followed by targeted integration of expression cassettes in the specific sites, provides an additional approach for boosting transgene expression and recombinant protein synthesis [65]. A promising integration site for expression and characterization of heterologous genes was identified in the genome of A. nidulans. Insertion of heterologous genes in the specific locus (Integration Site 1-IS1) did not interfere with the fitness of the strain, while it allowed for high and stable expression levels in a tissue-independent manner [66].

\subsection{Translational Regulation}

\section{Codon Usage and mRNA Stability}

Most of the amino acids found in nature are encoded by more than one codon (synonymous codons). The preference for one codon over another, known as codon usage, varies among organisms and can be a limitation when heterologous genes are expressed in a host with different codon usage compared 
to the codon usage of the organism from which the genes has been isolated [67]. Codon optimization is commonly used in such cases, where rare codons found in heterologous genes are replaced by synonymous codons that encode the same amino acid but are more frequently used in the expression host. Codon optimization has been proposed as a successful practice for improving mRNA stability and translational efficiency, leading to higher levels of heterologous protein production $[68,69]$.

Several studies in recombinant protein production in Aspergillus species have reported that codon optimized genes are expressed more efficiently, resulting in improved heterologous protein yields (Table 4) [69-72]. For example, A. oryzae strains carrying a codon optimized der f7, a gene that encodes Dermatophagoides farina mite allergen 7 , showed increased gene expression levels and it produced almost three to five more protein than the strains with the non-optimized gene [70]. Tanaka et al. (2012) showed later that the increase in transcriptional and translational efficiency was clearly assigned to improved mRNA stability due to codon optimization of $\operatorname{der} f 7$ [73].

Table 4. Approaches for improving recombinant protein production through codon optimization of the expressed sequences.

\begin{tabular}{|c|c|c|c|c|}
\hline Process & Modification & Performance & Improvement Factor & Reference \\
\hline \multirow[t]{3}{*}{ Codon usage } & $\begin{array}{c}\text { A Cyamopsis tetragonoloba } \\
\alpha \text {-galactosidase gene } \\
\text { optimized based on } \\
\text { Saccharomyces cerevisiae } \\
\text { codon usage and expressed } \\
\text { in A. awamori }\end{array}$ & $\begin{array}{c}\text { Synthetic gene: } 0.4 \mathrm{mg} / \mathrm{L} \\
\alpha \text {-galactosidase } \\
\text { Wild type gene: } \\
\text { Undetectable levels }\end{array}$ & - & [72] \\
\hline & $\begin{array}{c}\text { A Solanum tuberosum } \\
\alpha \text {-glucan phosphorylase } \\
\text { synthetic gene optimized } \\
\text { based on } A \text {. niger-preferred } \\
\text { codon usage for production } \\
\text { in } A \text {. niger }\end{array}$ & $\begin{array}{c}\text { Synthetic gene: } \\
\text { 39.6-94.6 mg/L } \alpha \text {-glucan } \\
\text { phosphorylase } \\
\text { Wild type gene: }<0.1 \mathrm{mg} / \mathrm{L}\end{array}$ & - & [71] \\
\hline & $\begin{array}{c}\text { A codon optimized } \\
\text { Dermatophagoides farina der f7 } \\
\text { gene based on A. oryzae } \\
\text { codon usage and expressed } \\
\text { in A. oryzae }\end{array}$ & $\begin{array}{l}\text { Non-fused: undetectable } \\
\text { level to a detectable level } \\
\text { Fused to GlaA: } 3 \text { to } 5 \text { fold } \\
\text { increase } \\
\text { (Signal intensity } \\
\text { quantification of the bands } \\
\text { from the SDS-PAGE) }\end{array}$ & $3-5$ & [70] \\
\hline
\end{tabular}

However, the codon usage of the native gene "donor" hosts is not trivial. It has been shown that codon usage influences local rates of translation elongation (preferred codons speed up elongation and rare codons slow it down), assisting in proper co-translational protein folding. This means that codon optimization of a genetic sequence that results in increased translation velocity, can also disrupt protein folding, secretion and activity [74].

In general, post-transcriptional events, such as mRNA processing (addition of the 3'polyA-tail or the $5^{\prime}$ cap) and base modifications, the presence of rare codons or destabilizing sequences can have an impact on the length and stability of mRNA, thus limiting efficient translation and protein synthesis [75]. Limitations related to mRNA stability can also be addressed by using gene fusions, which contain heterologous proteins fused to a well-secreted carrier protein [75], a strategy that will be discussed later in the review.

\subsection{Glycosylation}

Glycosylation is a post-translational modification of eukaryotic proteins, during which glycans are added on specific amino acid residues. Two main types of glycosylation have been described: the O-linked glycosylation, where glycans are added on the side-chain hydroxyl groups of serine or threonine residues [76], and the $N$-linked glycosylation, which takes place on the side-chain amino groups of asparagine residues (at a N-X-S/T motif, where $\mathrm{X}$ is any amino acid except proline) [77]. 
Glycosylation is crucial for glycoproteins, as it influences their stability, activity, but also their passage through the secretory pathway [78,79] (see also below Section 3.4.1. The fungal Secretory Pathway-Glycosylation).

Filamentous fungi, and thus aspergilli, have the ability to perform post-translational modifications, including glycosylation, making them appropriate hosts for production of eukaryotic proteins. However, when it comes to production of mammalian proteins, fungal glycosylation is a bottleneck [78]. Filamentous fungi typically produce $N$-glycans that differ in composition and structure from mammalian ones. This can create problems during heterologous production of mammalian proteins in fungal expression systems, such as incorrect folding and subsequent elimination of the aberrant proteins by the cell quality control mechanisms. Moreover, addition of unusual fungal glycan structures on the heterologous protein may affect its stability and activity, or in the case of therapeutic proteins, increase their immunogenicity [80].

During N-linked glycosylation, the glycan (Glc3Man9GlcNAc2), consisting of three glucose (Glc3), nine mannose (Man9), and two N-acetylglucosamine (GlcNAc2) residues, is transferred to the conserved consensus sequence Asn-X-Ser/Thr. Shortly after, the removal of three Glc and one Man sugar results in the Man8GlcNAc2 glucan, a process conserved among all eukaryotes. However, further modifications on Man8GlcNAc2 differ between mammalian and fungal cells. Filamentous fungi and yeasts usually produce small, high-mannose $N$-glycans, while the mammalian glycans are more complex, containing $N$-acetylglucosamine, galactose, fucose, and sialic acid.

Several attempts have been made to engineer the glycosylation pathway in aspergilli towards the synthesis of complex mammalian-like glycans [81-84]. Kainz et al. (2008) focused on two crucial steps in the pathway for obtaining glycoproteins of mammalian type: First, the trimming of terminal mannose residues from Man8GlcNAc2 to Man5GlcNAc2 structures, a process catalyzed by a mannosidase, and second, the subsequent transfer of $N$-acetylglucosamine to yield GlcNAcMan5GlcNAc2, catalyzed by a glycosyltransferase. Insertion of genes encoding the $\alpha-1,2$-mannosidase and $\beta-1,2-N$-acetylglucosaminyltransferase I in $A$. niger and $A$. nidulans resulted in the synthesis of glycans with the desirable structure described before. In addition, deleting a gene (algC) involved in the early steps of fungal glycosylation, further contributed to the synthesis of glycan structures resembling those of humanized glycoproteins [81].

\subsection{Secretion}

Another advantage of using Aspergillus species as protein production systems is their natural capacity to secrete high amounts of protein in the extracellular environment. Nevertheless, heterologous proteins often lack specific features of the native secreted proteins, leading to low secretion efficiency and low yields. Therefore, several studies have looked into unraveling the secretion processes in filamentous fungi $[85,86]$. In fact, multiple bottlenecks of the fungal secretory pathway have been identified and key factors of secretion have been engineered, improving production of heterologous proteins. Alternatively, fusion of these proteins to native, secreted proteins (carrier proteins) has also been able to enhance secretion, bypassing the complexity of engineering steps of fungal secretion [42].

\subsubsection{The fungal Secretory Pathway}

Proteins moving through the fungal secretory pathway are subjected to several quality control tests until they are finally secreted. Attempts to engineer fungal secretion have been made in all the possible rate-limiting steps, starting from the processing that occurs in the endoplasmic reticulum (ER), to protein transport and degradation pathways (Figure 1). 


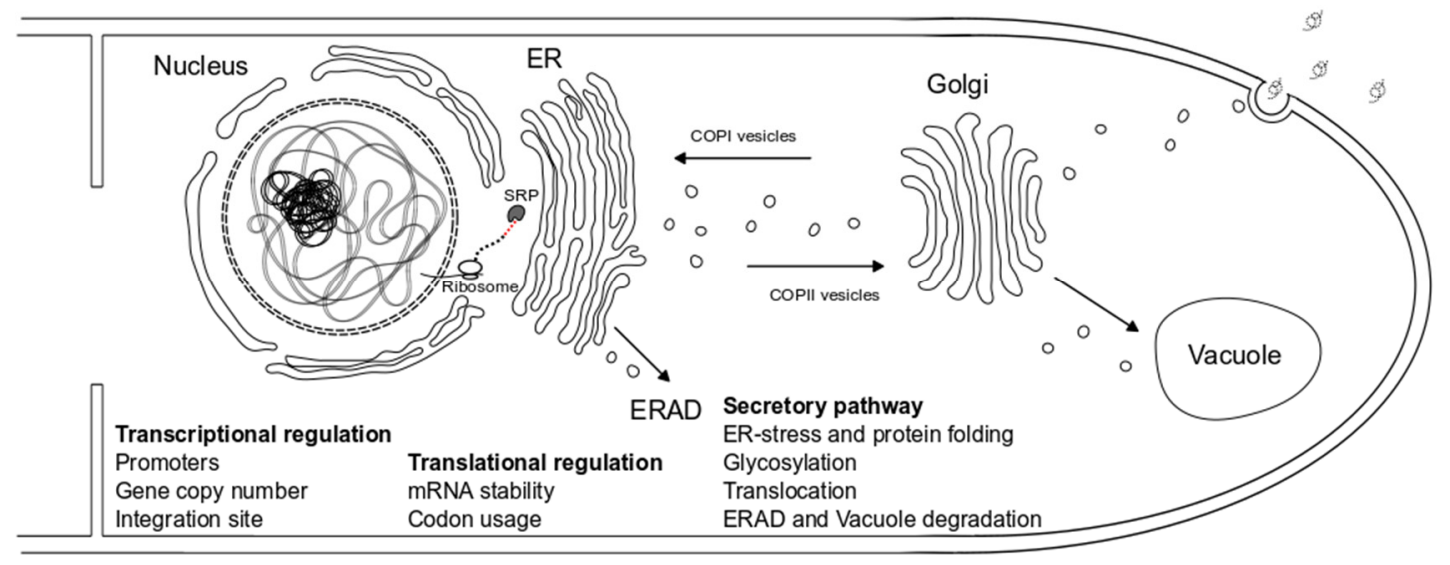

Figure 1. Protein synthesis and secretion in a fungal (e.g., A. niger) cell are schematically described. The figure also presents key steps that can be bottlenecks in the production of recombinant proteins in filamentous fungi. At transcription level, high expression of the gene of interest can be achieved by using strong promoters, integrating multiple gene copies and choosing integration sites that positively influences recombinant gene expression. Translation can also be a limiting step in recombinant protein production and can be improved by increasing mRNA stability and adjusting codon usage of the heterologous coding sequence to the fungal host. Following translation, proteins guided by the signal recognition particle (SRP) enter the ER lumen, where they receive post-translation modifications. At this stage, accumulation of unfolded proteins due to high gene expression can lead to ER-stress. Activation of several ER-resident chaperones and foldases (see text for details) can assist with proper folding of most proteins, relieving the overloaded ER. Proteins that fail to be properly folded are guided to the cytoplasm where they are degraded through the ERAD (ER-associated protein degradation) pathway by the proteasome. Proper folding, and consequently efficient secretion, is also dependent on the glycosylation process in the ER. Properly folded and glycosylated proteins destined to be secreted are packed into Coat Protein complex II (COPII) vesicles and transported to the Golgi complex, where further glycosylation takes place. Through a vesicle-mediated process, proteins finally reach the cell surface, where they are released into the periplasmic region. Additional protein translocation pathways, such as retrograde trafficking and vacuole degradation, can indirectly affect protein secretion efficiency. In retrograde trafficking, ER-resident proteins that have escaped or misfolded Golgi-resident proteins are transported from the Golgi back to the ER packed in COPI vesicles. Finally, misfolded and dysfunctional proteins that fail to pass the quality control of the secretory pathway can be transported to the vacuole by Vacuolar protein sorting (Vps) receptors and are degraded (autophagy-related degradation).

\section{- $\quad$ ER-stress and protein folding}

Secretion starts with the protein being transported to the ER, where post-translational modifications, like glycosylation, disulfide bond formation, and folding, take place. Accumulation of misfolded or unfolded proteins in the ER can activate stress response pathways in the cell, including the unfolded-protein response (UPR) and the ER-associated degradation (ERAD) pathway (Figure 1). Activation of the UPR usually increases expression of genes related to post-translation protein processing (e.g., lectins, chaperones, foldases, and protein disulfide isomerases), resulting in proper protein folding, and eventually alleviates ER-stress [87].

ER-overload is often observed in heterologous expression systems, where high transcriptional activity leads to buildup of incompletely folded proteins. As a result, efficient protein secretion is hindered, resulting in low production yields of heterologous proteins. In such cases, engineering the UPR is considered to be a promising practice to improve efficiency of heterologous expression systems [85]. Induction of the UPR by overexpressing the gene encoding the UPR transcription factor HacA in A. awamori increased production yields of the Trametes versicolor laccase by sevenfold 
and these of bovine preprochymosin by almost threefold [88]. In addition, constitutive expression of hacA resulted in 1.5 times higher production levels of neoculin, a plant nonglycemic sweetener, in A. oryzae cultures [40]. Many genetic engineering projects have also targeted single UPR components (e.g., ER-resident chaperones and foldases) for enhancing protein secretion in several Aspergillus species (Table 5) [88-93]. For example, overexpression of the gene encoding the lectin-like chaperone calnexin resulted in $60-73 \mathrm{mg} / \mathrm{L}$ of the Phanerochaete chrysosporium manganese peroxidase in A. niger mutants, while the parental strain production reached only $14 \mathrm{mg} / \mathrm{L}$ [92]. However, a positive correlation between chaperone overexpression and protein secretion appears to depend specifically on the protein to be produced. For example, increased production of the chaperone protein BipA negatively affected production of the P. chrysosporium manganese peroxidase in A. niger [92], but improved production titers of the plant sweet protein thaumatin in A. awamori [93].

Table 5. Approaches for improving recombinant protein production through engineering unfolded-protein response (UPR) response.

\begin{tabular}{|c|c|c|c|c|}
\hline Process & Modification & Performance & Improvement Factor & Reference \\
\hline \multirow[t]{3}{*}{$\begin{array}{l}\text { ER-stress and } \\
\text { protein folding }\end{array}$} & $\begin{array}{l}\text { Overexpression of } \\
\text { prpA (multicopy } \\
\text { integrated vector) } \\
\text { in } A \text {. niger } \\
\text { var. awamori }\end{array}$ & $\begin{array}{l}\text { The level of chymosin } \\
\text { by the control } \\
\text { transformants was } \\
\text { similar to the } \\
\text { transformants with } \\
\text { overexpression of } \\
\text { the prpA }\end{array}$ & - & [90] \\
\hline & $\begin{array}{c}\text { Deletion of prpA in } \\
\text { A. niger } \\
\text { var. awamori }\end{array}$ & $\begin{array}{l}\text { The production level of } \\
\text { bovine prochymosin } \\
\text { was lower than } \\
\text { expected for randomly } \\
\text { isolated transformants } \\
\text { (3/19 transformants) }\end{array}$ & - & {$[90]$} \\
\hline & $\begin{array}{l}\text { Overexpression of } \\
\text { cypB in } A \text {. niger }\end{array}$ & $\begin{array}{l}\text { Twofold increase in } \\
\text { glucoamylase } \\
\text { production }\end{array}$ & 2 & [89] \\
\hline & \multirow{2}{*}{$\begin{array}{c}\text { Insertion of } \\
\text { multiple copies of } \\
\text { pdiA in A. awamori }\end{array}$} & $\begin{array}{l}19 \mathrm{mg} / \mathrm{L} \text { thaumatin } \\
\text { compared to } 5 \mathrm{mg} / \mathrm{L} \text { in } \\
\text { the parental strain }\end{array}$ & 3.8 & \multirow[b]{2}{*}{ [91] } \\
\hline & & $\begin{array}{l}\text { Optimal bioreactor } \\
\text { conditions: } 150 \mathrm{mg} / \mathrm{L} \\
\text { thaumatin compared } \\
\text { to } 40 \mathrm{mg} / \mathrm{L} \text { in the } \\
\text { parental strain }\end{array}$ & 3.8 & \\
\hline & $\begin{array}{l}\text { Overexpression of } \\
\quad c l x A \text { in A.niger }\end{array}$ & $\begin{array}{c}\text { 60-73 mg/L } \\
\text { P. chrysosporium } \\
\text { manganese peroxidase } \\
\text { compared to } 14 \mathrm{mg} / \mathrm{L} \\
\text { in the parental strain }\end{array}$ & $4-5$ & [92] \\
\hline & $\begin{array}{l}\text { Overexpression of } \\
\text { bipA in A.niger }\end{array}$ & $\begin{array}{c}\text { P. chrysosporium } \\
\text { manganese peroxidase } \\
\text { was severely } \\
\text { reduced-almost } \\
\text { undetectable levels }\end{array}$ & - & [92] \\
\hline
\end{tabular}


Table 5. Cont.

\begin{tabular}{|c|c|c|c|c|}
\hline Process & Modification & Performance & Improvement Factor & Reference \\
\hline & \multirow{2}{*}{$\begin{array}{l}\text { Overexpression of } \\
\text { hacA in } A \text {. niger } \\
\text { var. awamori }\end{array}$} & $\begin{array}{l}\text { 13-34 mg/L chymosin } \\
\text { compared to } 12.5 \mathrm{mg} / \mathrm{L} \\
\text { in parental strain }\end{array}$ & $1.3-2.8$ & \multirow{2}{*}{ [88] } \\
\hline & & $\begin{array}{c}\text { 3.9-8.5 nkat } / \mathrm{mL} \text { laccase } \\
\text { compared to } \\
0.9 \mathrm{nkat} / \mathrm{mL} \text { in } \\
\text { parental strain }\end{array}$ & $3-7.6$ & \\
\hline & $\begin{array}{l}\text { Overexpression of } \\
\text { bipA in } A \text {. awamori }\end{array}$ & $\begin{array}{l}20 \mathrm{mg} / \mathrm{L} \text { thaumatin } \\
\text { compared to } 9 \mathrm{mg} / \mathrm{L} \text { in } \\
\text { the parental strain }\end{array}$ & $2-2.5$ & [93] \\
\hline & $\begin{array}{l}\text { Constitutive } \\
\text { expression of the } \\
\text { active form of hacA } \\
\text { cDNA in } A \text {. oryzae }\end{array}$ & $\begin{array}{l}2 \mathrm{mg} / \mathrm{L} \text { neoculin } \\
\text { compared to } 1.5 \mathrm{mg} / \mathrm{L} \\
\text { in the control strain }\end{array}$ & 1.5 & [40] \\
\hline
\end{tabular}

\section{- Glycosylation}

As mentioned before, glycosylation affects protein activity and stability and in many cases it also influences protein folding and secretion efficiency [78,79]. $\mathrm{N}$-glycosylation has been linked to an ER-quality control system of glycoprotein folding in filamentous fungi [94,95]. In fact, inhibiting the specific process in A. nidulans appeared to hinder secretion of $\alpha$-galactosidase, resulting in the accumulation of the under-glycosylated protein to the cell wall [96]. Engineering $N$-glycosylation has been applied as a strategy to increase levels of heterologous protein secretion (Table 6) [97-99]. For example, improving a poorly used $N$-glycosylation site or adding a new one in a chymosin gene almost doubled the levels of secreted protein in A. niger strains [98].

Table 6. Approaches for improving recombinant protein production through engineering glycosylation.

\begin{tabular}{|c|c|c|c|c|}
\hline Process & Modification & Performance & Improvement Factor & Reference \\
\hline \multirow[t]{5}{*}{ Glycosylation } & $\begin{array}{c}\text { Overexpression of } \\
\text { S. cerevisiae DPM1 in } \\
\text { A. nidulans strains } \\
\text { impaired in DPMS activity }\end{array}$ & $\begin{array}{l}\text { No significant increase in } \\
\text { protein secretion observed } \\
\text { Production of invertase and } \\
\text { glucoamylase was higher but } \\
\text { the proteins were trapped in } \\
\text { the periplasmic space }\end{array}$ & 28 & [97] \\
\hline & \multirow{4}{*}{$\begin{array}{l}\text { Deletion of mnn9, mnn10, } \\
\text { ochA in } A . \text { niger }\end{array}$} & $\begin{array}{l}\Delta \text { mnn9: } 14.6 \% \text { increase in } \\
\text { Tramete laccase production }\end{array}$ & 1.1 & \multirow{4}{*}{ [99] } \\
\hline & & $\Delta$ mnn10: $12.7 \%$ increase & 1.1 & \\
\hline & & $\Delta$ ochA: $7.2 \%$ increase & 1.1 & \\
\hline & & $\Delta \mathrm{mnn} 9 / \mathrm{och} A: 16.8 \%$ increase & 1.2 & \\
\hline
\end{tabular}


Strangely enough, it appears that glycosylation is not always essential for the secretion of proteins. For example, secretion of $\alpha$-amylase was not affected at all when the antibiotic tunicamycin was used to block $N$-glycosylation in $A$. oryzae cultures [79]. In another attempt, overexpressing the yeast DPM1 gene, a key gene of $O$-glycosylation, improved the generation of native proteins in $O$-glycosylation-deficient $A$. nidulans strains, but the proteins produced were mostly localized in the periplasmic space [97]. In addition, deleting $a l g C$, a gene involved in early steps of $N$-glycosylation, resulted in an increase of the overall protein secretion in A. niger strains [100]. It is apparent that the role of glycosylation in protein production is not yet clearly understood and requires more research in order to be employed for improving heterologous protein production.

\section{- Protein translocation}

Following glycosylation and quality control in the ER, secreted proteins are packed in ER-derived vesicles (COPII-coated vesicles) and are transported to the Golgi apparatus. Proteins are further glycosylated there and are then guided to the plasma membrane in Golgi-derived vesicles. Additionally, other types of vesicles starting from Golgi carry ER-residents back to the ER or recycle important Golgi-enzymes and trafficking components (COPI-coated vesicles) [101] (Figure 1).

Regulating expression of key factors involved in vesicle trafficking (e.g., cargo receptors recruiting proteins into the vesicles) has been applied lately in order to assist protein transport through the secretory pathway and has improved production yields in aspergilli (Table 7) [61,102-104]. Indicatively, overproduction of the Rab GTPase RabD, a protein involved in cargo transport from the Golgi apparatus to the plasma membrane, increased the secretion yields of a fluorescent reporter protein (mRFP) in A. nidulans cultures by approximately $25 \%$ [61]. Similarly, deleting genes encoding the receptors AoVip36 and AoEmp47, which retain proteins in the ER, almost doubled the level of chymosin secreted in A. oryzae strains [104].

Table 7. Projects for improving recombinant protein production through engineering protein trafficking.

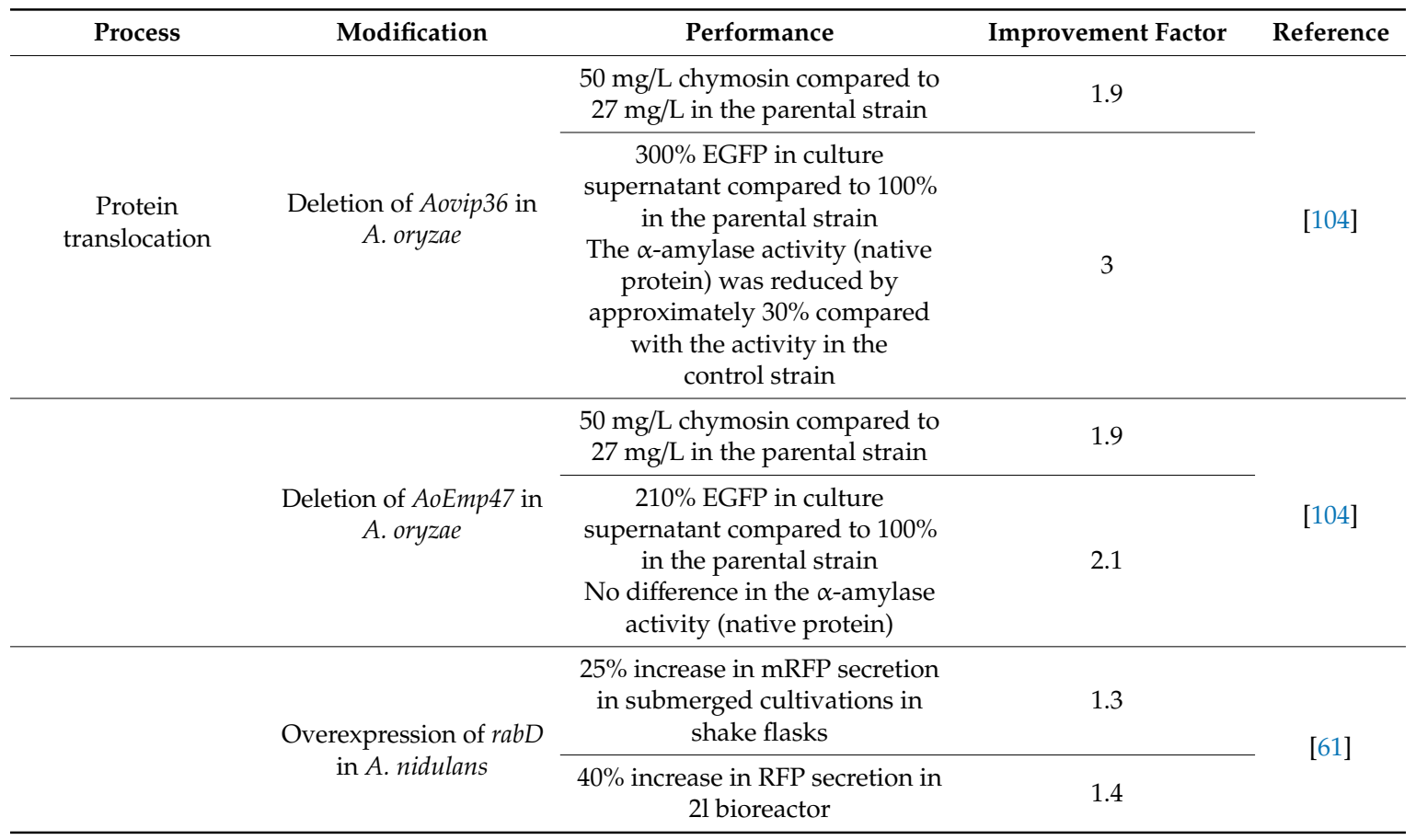


Table 7. Cont.

\begin{tabular}{|c|c|c|c|c|}
\hline Process & Modification & Performance & Improvement Factor & Reference \\
\hline & $\begin{array}{c}\text { Deletion of } r a c A \text { in } \\
\text { A. niger }\end{array}$ & $\begin{array}{l}\text { Native GlaA secreted into the } \\
\text { culture medium is four times } \\
\text { more compared to its parental } \\
\text { strain, when ensuring } \\
\text { continuous high-level } \\
\text { expression of glaA. } \\
\text { Quantification was done by dot } \\
\text { blot analysis using a monoclonal } \\
\text { antibody (Arbitrary units) }\end{array}$ & 4 & [102] \\
\hline & $\begin{array}{l}\text { Overexpression of arfA } \\
\quad \text { in } A \text {. niger }\end{array}$ & $\begin{array}{c}\text { Quantitative abundance of } \\
\text { GlaA-dtomato reporter protein } \\
\text { was } 397.4 \text { absolute fluorescence } \\
\text { compared to } 298.7 \text { in } \\
\text { control strain }\end{array}$ & 1.3 & [103] \\
\hline
\end{tabular}

- Protein degradation pathways-ERAD and Vacuole

Misfolded proteins that fail to be refolded properly through the UPR enter the ERAD pathway (Figure 1). They are transported from the ER to the cytoplasm, where they are ubiquitinated and degraded by the proteasome [105]. Disrupting key genes of the ERAD has been applied in order to study intracellular degradation of heterologous proteins and improve production yields in Aspergillus species (Table 8) $[99,106,107]$. Inactivation of doaA, which encodes a factor required for ubiquitin-mediated proteolysis, combined with induction of UPR-related genes (sttC) contributed to improved heterologous protein expression in A. niger [106].

Table 8. Approaches for improving recombinant protein production through engineering protein degradation pathways.

\begin{tabular}{|c|c|c|c|c|}
\hline Process & Modification & Performance & Improvement Factor & Reference \\
\hline \multirow{7}{*}{$\begin{array}{c}\text { Protein } \\
\text { degradation } \\
\text { pathways-ERAD } \\
\text { and Vacuole }\end{array}$} & $\begin{array}{l}\text { Deletion of } \operatorname{der} A \text { and } \\
\operatorname{der} B \text { in } A . \text { niger }\end{array}$ & $\begin{array}{c}\Delta \text { derA: } 80 \% \text { decrease in Tramete } \\
\text { laccase production }\end{array}$ & 0.2 & \multirow{2}{*}{ [99] } \\
\hline & - & $\begin{array}{c}\Delta \text { derB: } 15.7 \% \text { increase in } \\
\text { Tramete laccase }\end{array}$ & 1.15 & \\
\hline & $\begin{array}{l}\text { Deletion of doaA and } \\
\text { overexpression of sttC } \\
\text { in A. niger }\end{array}$ & $\begin{array}{c}\text { Higher GUS activity compared } \\
\text { to parental strain } \\
\text { (no quantitative data available) }\end{array}$ & - & [106] \\
\hline & \multirow{2}{*}{$\begin{array}{l}\text { Disruption of Aovps10 } \\
\quad \text { in A. oryzae }\end{array}$} & $\begin{array}{c}83.1 \text { and } 70.3 \mathrm{mg} / \mathrm{L} \text { chymosin } \\
\text { compared to } 28.7 \mathrm{mg} / \mathrm{L} \text { in } \\
\text { parental strain }\end{array}$ & $3-2.5$ & \multirow{2}{*}{ [108] } \\
\hline & & $\begin{array}{l}22.6 \text { and } 24.6 \mathrm{mg} / \mathrm{L} \text { human } \\
\text { lysozyme compared to } \\
11.1 \mathrm{mg} / \mathrm{L} \text { in parental strain }\end{array}$ & $2-2.2$ & \\
\hline & \multirow[b]{2}{*}{$\begin{array}{l}\text { Deletion of ERAD key } \\
\text { genes (der } A, \text { doaA, } \\
\text { hrdC, mifA and } m n s A) \\
\text { in } A . \text { niger }\end{array}$} & $\begin{array}{l}\Delta \text { derA and } \Delta \text { hrdC: } 2 \text {-fold } \\
\text { increase compared to parental } \\
\text { strain (single-copy) }\end{array}$ & 2 & \multirow[b]{2}{*}{ [107] } \\
\hline & & $\begin{array}{c}\Delta \text { derA: 6-fold increase } \\
\text { compared to parental strain } \\
\text { (multi-copy) } \\
\text { Relative amount of intracellular } \\
\text { GlaGus ( } \beta \text {-glucuronidase levels) } \\
\text { fusion protein detected in total } \\
\text { protein extracts of strains with } \\
\text { impaired ERAD and respective } \\
\text { parental strain }\end{array}$ & 6 & \\
\hline
\end{tabular}


Table 8. Cont.

\begin{tabular}{|c|c|c|c|c|}
\hline Process & Modification & Performance & Improvement Factor & Reference \\
\hline & \multirow{6}{*}{$\begin{array}{l}\text { Disruption of genes } \\
\text { involved in autophagy } \\
\text { in A. oryzae }\end{array}$} & $\Delta$ Aoatg1: $60 \mathrm{mg} / \mathrm{L}$ chymosin & 2.3 & \multirow{6}{*}{ [109] } \\
\hline & & $\Delta$ Aoatg13: $37 \mathrm{mg} / \mathrm{L}$ chymosin & 1.4 & \\
\hline & & $\Delta$ Aoatg4: $80 \mathrm{mg} / \mathrm{L}$ chymosin & 3.1 & \\
\hline & & $\Delta$ Aoatg8: $66 \mathrm{mg} / \mathrm{L}$ chymosin & 2.5 & \\
\hline & & $\Delta$ Aoatg15: $24 \mathrm{mg} / \mathrm{L}$ chymosin & 1 & \\
\hline & & Control: $26 \mathrm{mg} / \mathrm{L}$ chymosin & - & \\
\hline
\end{tabular}

During the last steps of secretion additional protein quality control mechanisms can target aberrant proteins to degradation. During autophagy proteins are guided through vesicle trafficking to vacuoles, where they get degraded (Figure 1). Disruption of the autophagic process has been proposed as a way to enhance production of recombinant heterologous proteins (Table 8) [108,109]. For example, deleting the vacuolar protein sorting receptor gene AoVPS in A. oryzae resulted in increased extracellular production levels of chymosin and human lysozyme in A. oryzae by 3- and 2-fold, respectively [108].

Collectively, these studies suggest that the fungal secretory pathway offers multiple engineering targets and opens up a new perspective on developing hypersecreting Aspergillus strains for industrial applications.

\subsubsection{Carrier Proteins}

A commonly applied approach for successful secretion of foreign proteins in Aspergillus cultures is the use of native, well-secreted carrier proteins. Fusion of a carrier protein to heterologously produced proteins appears to improve mRNA stability [75] and facilitate proper folding and translocation through the fungal secretory pathway [110]. Multiple proteins of industrial and pharmaceutical relevance have been produced and efficiently secreted following this strategy. Chymosin, a protease used as a milk clotting agent in cheese manufacturing, was one of the first examples of a heterologous protein to be produced in Aspergillus cultures using the natively secreted glucoamylase A (GlaA) as a carrier protein [111,112] or just the GlaA signal peptide [113]. Since then, the advantages of using entire or parts of carrier proteins were exploited further for the production of human interleukin-6 [114], antibodies $[115,116]$, and other commercially relevant proteins $[40,117]$ in several Aspergillus species improving production yields (Table 9).

As GlaA is the most abundant and highly secreted enzyme in most Aspergillus species, it is a popular carrier choice for heterologous protein production $[113,114,116,117]$. However, other naturally secreted proteins, or their signal peptides, have also been used successfully for this purpose, e.g., the A. oryzae $\alpha$-amylase $[40,118,119]$ and signal peptides of an A. niger endoxylanase [120] (Table 9).

Table 9. Approaches for improving recombinant protein production through the use of carrier proteins.

\begin{tabular}{ccccc}
\hline Process & Modification & Performance & Improvement Factor & Reference \\
\hline Carriers & $\begin{array}{c}\text { Prochymosin sequence } \\
\text { fused to } \text { A. niger GlaA signal } \\
\text { peptide in A. nidulans }\end{array}$ & $\begin{array}{c}146 \mu \mathrm{g} / \mathrm{g} \text { dry weight } \\
\text { chymosin compared to } \\
93 \mu \mathrm{g} / \mathrm{g} \text { dry weight in the } \\
\text { control strain }\end{array}$ & 1.56 & [113] \\
\hline & $\begin{array}{c}\text { Prochymosin sequence fused } \\
\text { to codons for the GlaA signal } \\
\text { peptide, propeptide, and } 11 \\
\text { amino acids of mature } \\
\text { glucoamylase in } A \text {. nidulans }\end{array}$ & $\begin{array}{c}119 \mu \mathrm{g} / \mathrm{g} \text { dry weight } \\
\text { chymosin compared to } 93 \\
\mu \mathrm{g} \text { dry weight in the } \\
\text { control strain }\end{array}$ & 1.27 & [113] \\
\hline
\end{tabular}


Table 9. Cont.

\begin{tabular}{|c|c|c|c|c|}
\hline \multirow[t]{6}{*}{ Process } & Modification & Performance & Improvement Factor & Reference \\
\hline & $\begin{array}{l}\text { Prochymosin sequence fused } \\
\text { to GlaA signal peptide and } \\
\text { propeptide in } A \text {. nidulans }\end{array}$ & $\begin{array}{c}23 \mu \mathrm{g} / \mathrm{g} \text { dry weight } \\
\text { compared to } 93 \mu \mathrm{g} / \mathrm{g} \text { dry } \\
\text { weight in the control strain }\end{array}$ & 0.24 & [113] \\
\hline & $\begin{array}{l}\text { Prochymosin sequence } \\
\text { fused after the last codon of } \\
\text { A. awamori GlaA in } \\
\text { A. awamori }\end{array}$ & $\begin{array}{c}140 \mu \mathrm{g} / \mathrm{mL} \text { secreted } \\
\text { chymosin compared to } 8 \\
\mu \mathrm{g} / \mathrm{mL} \text { in the control strain } \\
\text { (prochymosin + GlaA } \\
\text { signal peptide) }\end{array}$ & 17.5 & {$[111,112]$} \\
\hline & $\begin{array}{l}\text { hlL6 fused to } 1-514 \mathrm{nt} \text { of } \\
\text { A. niger GlaA in A. niger }\end{array}$ & $\begin{array}{l}15 \mathrm{mg} / \mathrm{L} \text { hIL6 compared to } \\
\text { less than } 1 \mu \mathrm{g} / \mathrm{L} \text { in the } \\
\text { control strain (hlL6 fused to } \\
\text { the GlaA signal peptide) }\end{array}$ & $>15$ & [114] \\
\hline & \multirow{2}{*}{$\begin{array}{c}\text { E. coli uidA } \\
\text { (13-glucuronidase) and the } T \text {. } \\
\text { lanuginosa lipase fused to } A \text {. } \\
\text { niger var. awamori } \\
\text { endoxylanase II } \\
\text { secretion signals }\end{array}$} & $\begin{array}{l}798 \text { Arbitrary units of } \\
\text { glucuronidase activity/mg of } \\
\text { total protein (the control did } \\
\text { not carry uidA) }\end{array}$ & - & \multirow[t]{2}{*}{ [120] } \\
\hline & & $\begin{array}{l}\text { 47.5 Arbitrary units of lipase } \\
\text { activity compared to } 47 \\
\text { Arbitrary units when the } \\
\text { native lipase signal is used }\end{array}$ & 1 & \\
\hline & $\begin{array}{l}\text { ScFv-LYS encoding } \\
\text { fragments fused to A. niger } \\
\text { propeptide + GlaA (514nt) }\end{array}$ & $\begin{array}{c}90 \mathrm{mg} / \mathrm{L} \mathrm{ScFv}-\mathrm{LYS} \text { compared } \\
\text { to } 2-22 \mathrm{mg} / \mathrm{L} \text { in the control } \\
\text { strains }(18 \text { aa GlaA signal } \\
\text { sequence }+\mathrm{ScFv}-\mathrm{LYS})\end{array}$ & $4-45$ & [115] \\
\hline & $\begin{array}{l}\text { Human antibodies ( } \kappa \text { - and } \\
\gamma \text {-chain of IgG1) fused to } \\
\text { GlaA in A. niger }\end{array}$ & $\begin{array}{l}0.9 \mathrm{~g} / \mathrm{L} \text { of trastuzumab IgG1 } \\
\text { and } 0.2 \mathrm{~g} / \mathrm{L} \text { of Hu1D10 }\end{array}$ & - & [116] \\
\hline & $\begin{array}{l}\text { Neoculin gene fused to } \\
\alpha \text {-amylase in } A \text {. oryzae }\end{array}$ & $1.3 \mathrm{mg} / \mathrm{L}$ of NCL & - & {$[40]$} \\
\hline & $\begin{array}{l}\text { Bovine chymosin gene fused } \\
\text { to } \alpha \text {-amylase in } A \text {. oryzae }\end{array}$ & $\begin{array}{c}42 \mathrm{mg} / \mathrm{L} \text { chymosin compared } \\
\text { to } 20 \mathrm{mg} / \mathrm{L} \text { in strains with } \\
\text { non-fused gene }\end{array}$ & 2.1 & [119] \\
\hline & $\begin{array}{c}\text { Hemicellulose degrading } \\
\text { enzymes sequences fused to } \\
\text { GlaA secretion peptide in } A \text {. } \\
\text { nidulans strains }\end{array}$ & $\begin{array}{c}50-100 \mathrm{mg} / \mathrm{L} \text { xylanase } \mathrm{B}, \\
\text { xylanase } \mathrm{C} \text {, xylosidase } \mathrm{D}, \\
\text { arabinofuranosidase } \mathrm{B}, \\
\text { ferulic acid esterase } \\
\text { and arabinase }\end{array}$ & - & [117] \\
\hline
\end{tabular}

Regardless of the carrier protein or the signal peptide used, the heterologous protein needs to be detached from the protein fusion after secretion in order to gain full activity. An alternative practice to downstream in vitro treatment with proteases is to incorporate a protease cleavage site (e.g., Lys-Arg) between the native and the foreign protein, which can be proteolytically cleaved by fungal endoproteases (e.g., KEXB endoprotease in A. niger) during secretion [114,121,122]. Optimization of the sequence upstream the KEXB cleavage site appeared to increase Trastuzumab light chain production in A. niger [122].

\subsection{Proteases}

Proteolytic degradation by extracellular fungal proteases is one of the main reasons why secreted yields of heterologous proteins fail to reach the gram-per-liter production level of native proteins in Aspergillus species. Several bioprocessing strategies, such as maintaining high $\mathrm{pH}$ during fermentation [123] or low temperatures during downstream processing, separating the product from the protease-containing medium and using protease inhibitors, are often used to decrease protein degradation. However, proteolysis still occurs, making production of foreign proteins inefficient [124].

An alternative and more efficient approach is the use of protease-deficient strains [124]. Conventional mutagenesis and genetic engineering were applied to several Aspergillus species 
in order to disrupt genes that encode extracellular proteases, e.g., aspergillopepsin A (pepA) [125,126] or protease regulatory genes $[126,127]$ (Table 10$)$. The specific mutants exhibit reduced extracellular proteolytic activity and often appear to be more efficient producers of heterologous proteins than the wild types [124]. Deletion of pepA in A. awamori resulted in an aspergillopepsin A-deficient mutant, with decreased proteolytic activity [125] and able to produce higher levels of bovine chymosin $(\sim 430 \mathrm{mg} / \mathrm{L})$, when compared to the control strain (A. awamori strain GC12- $\operatorname{argB3}, \Delta$ pyrG5: $180 \mathrm{mg} / \mathrm{L}$ ) [128]. A. niger mutants lacking the transcription factor PrtT, which regulates expression of both aspergillopepsin $\mathrm{A}$ and B genes (рерA and pepB) [129], showed only $1-2 \%$ of the parental strain extracellular protease activity [126] and were used to produce highly stable heterologous cutinase with 1.7-fold increased activity [127].

Table 10. Approaches for improving recombinant protein production through disruption of protease genes.

\begin{tabular}{|c|c|c|c|c|}
\hline Process & Modification & Performance & Improvement Factor & Reference \\
\hline \multirow[t]{21}{*}{ Proteases } & $\begin{array}{l}\text { Deletion of pepA in } \\
\text { A. awamori strains }\end{array}$ & $\begin{array}{l}\text { Decreased extracellular proteolytic activity } \\
\text { compared to the wild type (immunoassay using } \\
\text { antibodies specific for PepA, but absolute values } \\
\text { for PepA concentration were not determined) }\end{array}$ & - & [125] \\
\hline & $\begin{array}{l}\text { Deletion of pepA in } \\
\text { A. awamori }\end{array}$ & $\begin{array}{l}430 \mathrm{mg} / \mathrm{L} \text { of chymosin compared to } 180 \mathrm{mg} / \mathrm{L} \text { in the } \\
\text { parental strain }\end{array}$ & 2.4 & [128] \\
\hline & $\begin{array}{l}\text { Deletion of pepA in } \\
\text { A. niger (AB1.18) }\end{array}$ & $\begin{array}{l}15-20 \% \text { proteolytic activity compared to the parent } \\
\text { strain AB4.1 }\end{array}$ & - & [126] \\
\hline & $\begin{array}{l}\text { Mutation on } p r t T \text { (UV } \\
\text { irradiation) in } A \text {. niger } \\
\text { (AB1.13) }\end{array}$ & $\begin{array}{l}1-2 \% \text { proteolytic activity compared to the parent } \\
\text { strain AB4.1 }\end{array}$ & - & [126] \\
\hline & \multirow{4}{*}{$\begin{array}{l}\text { Deletion of } p r t R, p e p A, \\
c p I, t p p A \text { in } A . \text { oryzae }\end{array}$} & $\begin{array}{l}\Delta \mathrm{prtR} / \mathrm{pepA} / \mathrm{cpI}: 24.23 \mathrm{mg} / \mathrm{L} \text { of Acremonium } \\
\text { cellulolyticus cellobiohydrolase }\end{array}$ & 1.2 & \multirow{4}{*}{ [133] } \\
\hline & & $\Delta$ prtR/pepA/tppA: $21.30 \mathrm{mg} / \mathrm{L}$ & 1.1 & \\
\hline & & $\Delta$ prtR/cpI/tppA: 22.08 mg/L & 1.1 & \\
\hline & & $\begin{array}{c}\Delta \text { prtR/pepA/cpI/tppA: } 19.93 \mathrm{mg} / \mathrm{L} \text { compared to } \\
19.54 \mathrm{mg} / \mathrm{L} \text { in the control strains }\end{array}$ & 1.02 & \\
\hline & $\begin{array}{l}\text { Deletion of alp and } N p l \\
\text { in A. oryzae }\end{array}$ & $\begin{array}{c}1041 \mathrm{U} / \mathrm{g} \text { of Candida antarctica lipase B compared to } \\
575 \mathrm{U} / \mathrm{g} \text { in the parental strains }\end{array}$ & 1.8 & [132] \\
\hline & \multirow{9}{*}{$\begin{array}{l}\text { Deletion of various } \\
\text { proteases in } A \text {. niger }\end{array}$} & $\Delta$ dpp4: $6 \%$ increase in Tramete laccase & 1.1 & \multirow{9}{*}{ [99] } \\
\hline & & $\Delta$ dpp5: $15.4 \%$ increase & 1.2 & \\
\hline & & $\Delta$ pepB: $8.6 \%$ increase & 1.1 & \\
\hline & & $\Delta$ pepD: $4.8 \%$ increase & 1.0 & \\
\hline & & $\Delta$ pepF: $5.3 \%$ increase & 1.1 & \\
\hline & & $\Delta$ pepAa: $0.5 \%$ increase & 1.1 & \\
\hline & & $\Delta$ pepAb: $13.4 \%$ increase & 1.1 & \\
\hline & & $\Delta$ pepAd: $2.7 \%$ increase & 1.0 & \\
\hline & & $\Delta$ dpp4/dpp5: $26.6 \%$ increase & 1.3 & \\
\hline & $\begin{array}{l}\text { Disruption of } t p p A \text { and } \\
\text { pepE in } A \text {. oryzae strains }\end{array}$ & $\begin{array}{l}25.4 \mathrm{mg} / \mathrm{L} \text { of human lysozyme compared to } \\
15 \mathrm{mg} / \mathrm{L} \text { in the parental strains }\end{array}$ & 1.7 & [118] \\
\hline & $\begin{array}{l}\text { Disruption of } t p p A, \\
\text { pepE, } n p t B, d p p I V \text { and } \\
d p p V \text { in } A \text {. oryzae }\end{array}$ & $\begin{array}{c}84.4 \mathrm{mg} / \mathrm{L} \text { of chymosin compared to the } 63.1 \mathrm{mg} / \mathrm{L} \\
\text { in the double protease gene disruptant } \\
(\Delta \text { tppA/pepE) }\end{array}$ & 1.3 & [130] \\
\hline & $\begin{array}{l}\text { Disruption of tppA, } \\
\text { pepE, nptB, dppIV, and } \\
\operatorname{dpp} V, \operatorname{alp} A, p e p A, \\
\text { AopepAa, AopepAd and } \\
\text { cpI in A. oryzae }\end{array}$ & $\begin{array}{l}109.4 \mathrm{mg} / \mathrm{L} \text { of chymosin and } 35.8 \mathrm{mg} / \mathrm{L} \text { of human } \\
\text { lysozyme compared to the quintuple protease gene } \\
\text { disruptant }(\Delta \operatorname{tppA} / \mathrm{pepE} / \mathrm{nptB} / \mathrm{dpp} I V / \mathrm{dppV} \\
84.4 \mathrm{mg} / \mathrm{L} \text { and } 26.5 \mathrm{mg} / \mathrm{L} \text {, respectively) }\end{array}$ & 1.3 and 1.35 & [131] \\
\hline
\end{tabular}


Table 10. Cont.

\begin{tabular}{|c|c|c|c|c|}
\hline Process & Modification & Performance & Improvement Factor & Reference \\
\hline & \multirow[b]{2}{*}{$\begin{array}{l}\text { Deletion of } p r t T \text { in } \\
\quad \text { A. niger }\end{array}$} & $\begin{array}{l}\text { 36.3-36.7 U/mL of } \mathrm{mL} \mathrm{G} \text {. cingulate cutinase } \\
\text { compared to } 21.2-20.4 \mathrm{U} / \mathrm{mL} \text { in the parental strain }\end{array}$ & 1.7 & \multirow[b]{2}{*}{ [127] } \\
\hline & & $\begin{array}{l}\text { Stability: Cutinase activity retained at } 80 \% \text { over the } \\
\text { entire } 14 \text {-day incubation period, while the parental } \\
\text { lost more than } 50 \% \text { of their initial activities after six } \\
\text { days of incubation and retained negligible activity } \\
\text { after } 14 \text { days }\end{array}$ & - & \\
\hline & $\begin{array}{l}\text { Deletion of } d p p V \text { and } \\
\text { pepA in } A \text {. nidulans }\end{array}$ & $\begin{array}{l}\text { P. sanguineus laccase activity } 0.5 \mathrm{U} / \mathrm{mL} \text { compared to } \\
\qquad 0.04 \mathrm{U} / \mathrm{mL} \text { in the control strain }\end{array}$ & 12.5 & [51] \\
\hline & $\begin{array}{l}\text { Deletion of mnn9 and } \\
\text { pepA in } A \text {. nidulans }\end{array}$ & $\begin{array}{l}\text { P. sanguineus laccase activity } 0.3 \mathrm{U} / \mathrm{mL} \text { compared to } \\
\qquad 0.04 \mathrm{U} / \mathrm{mL} \text { in the control strain }\end{array}$ & 7.5 & {$[51]$} \\
\hline
\end{tabular}

Research on Aspergillus protease repertoire and development of molecular tools for multiple gene targeting allowed the disruption of multiple protease-related genes in a single production host, a successful tactic to further decrease proteolytic degradation and therefore improve protein production titers (Table 10) $[51,118,130,131]$. Disruption of two protease genes in A. oryzae (tppA and pepE) resulted in production of $25.4 \mathrm{mg} / \mathrm{L}$ of human lysozyme (HLY), which represents a $63 \%$ increase in production yields compared to the control strain [118]. Subsequently, A. oryzae quintuple and decuple protease gene disruptants produced even higher HLY amounts $(26.5 \mathrm{mg} / \mathrm{L}$ and $35.8 \mathrm{mg} / \mathrm{L}$, respectively) [130,131]. Although multiple protease-related gene disruptions appear to be a time-consuming and tedious procedure [127], it is a strategy commonly used for the optimization of heterologous protein production in several Aspergillus systems of industrial interest [99,132,133].

\subsection{Altering Fungal Morphology Using Genetic Engineering}

Protein secretion in filamentous fungi has been shown to happen mostly at the tip of growing hypha, thus hyperbranched phenotypes are more desirable when developing a protein production platform. Additionally, combining a hyperbranched phenotype with shortened mycelia may result in reduced culture viscosity, which is beneficial for high density submerged fermentation $[134,135]$.

Multiple studies have focused on the effect of morphology on protein production in aspergilli. Genetic engineering attempts $[102,103]$ (Table 11) or variation of fermentation parameters (see also Section 4.2.: Fungal morphology and bioprocessing) have been employed to obtain hyperbranching strains that can secrete large amounts of proteins. In $A$. niger deleting the gene that encodes the Rho-GTPase RacA, which mediates actin polymerization and depolymerisation at the hyphal apex, generated a strain producing $20 \%$ more hyphal tips. Under continuous high-level expression, this hyperbranching strain produced four times more glucoamylase compared to its parental strain [102].

Table 11. Approaches for improving recombinant protein production through engineering genes involved in fungal morphology.

\begin{tabular}{|c|c|c|c|c|}
\hline Process & Modification & Performance & Improvement Factor & Reference \\
\hline $\begin{array}{l}\text { Fungal } \\
\text { morphology }\end{array}$ & $\begin{array}{l}\text { Deletion of racA in } \\
\text { A. niger }\end{array}$ & $\begin{array}{l}\text { GlaA secreted into the culture } \\
\text { medium is four times more } \\
\text { compared to its parental strain, } \\
\text { when ensuring continuous } \\
\text { high-level expression of glaA. } \\
\text { Quantification was done by dot } \\
\text { blot analysis using a monoclonal } \\
\text { antibody (Arbitrary units) }\end{array}$ & 4 & [102] \\
\hline & $\begin{array}{c}\text { Overexpression of } \\
\operatorname{arf} A \text { in } A . \text { niger }\end{array}$ & $\begin{array}{l}\text { Quantitative abundance of } \\
\text { GlaA-dtomato reporter protein } \\
\text { was } 397.4 \text { absolute fluorescence } \\
\text { compared to } 298.7 \text { in control strain }\end{array}$ & 1.3 & [103] \\
\hline
\end{tabular}




\section{Fermentation Conditions for Improved Heterologous Production in Aspergillus}

Development of most heterologous expression platforms begins with strain improvement, which hopefully results in obtaining strains able to produce large quantities of a specific protein. Once strain improvement is complete, the fermentation process for production of the desirable protein in large-scale has to be established $[7,136]$. Designing and setting up fungal fermentations is a complex process that has to be repeated every time a newly engineered strain is used or a new protein is to be produced. This process requires several optimization steps, starting from finding the optimal growth medium and fermentation parameters (temperature, $\mathrm{pH}$, and oxygenation) to choosing the appropriate type of fermentation and the fungal morphology that favors high production yields of the specific protein [137-139].

\subsection{Fermentation Conditions}

Multiple strategies have been applied to optimize fermentation conditions for improving recombinant protein production in Aspergillus cultures (Table 12). Several studies have focused on the effect of growth medium and culture conditions on protein production [140-145]. MacKenzie et al. (1994) studied the effect that temperature and growth medium have on the production of hen eggwhite lysozyme (HEWL) in A. niger cultures. When a standard expression medium ( $1 \%$ w/v soluble starch and $50 \mathrm{mM}$ sodium phosphate buffer) was used, $20-25^{\circ} \mathrm{C}$ was the optimal temperature range to obtain lysozyme in previously observed levels $(8-10 \mathrm{mg} / \mathrm{L})$. In addition, as the HEWL gene was under the control of the glaA promoter, production of lysozyme was highly induced when soluble starch was used as carbon source. Using a richer medium with soy milk led to even higher yields of up to $30-60 \mathrm{mg} / \mathrm{L}$ lysozyme, but interestingly growth temperature was adjusted to $37^{\circ} \mathrm{C}$ to achieve these levels [141]. In another attempt, the impact of the nitrogen source was evaluated [143]. Swift et al. (2000) showed that glucoamylase production was increased by $115 \%$ with the addition of casamino acids, yeast extract, peptone, and gelatin in cultures of a recombinant $A$. niger strain, compared to non-supplemented cultures [143].

Table 12. Approaches for improving recombinant protein production through bioprocessing modifications.

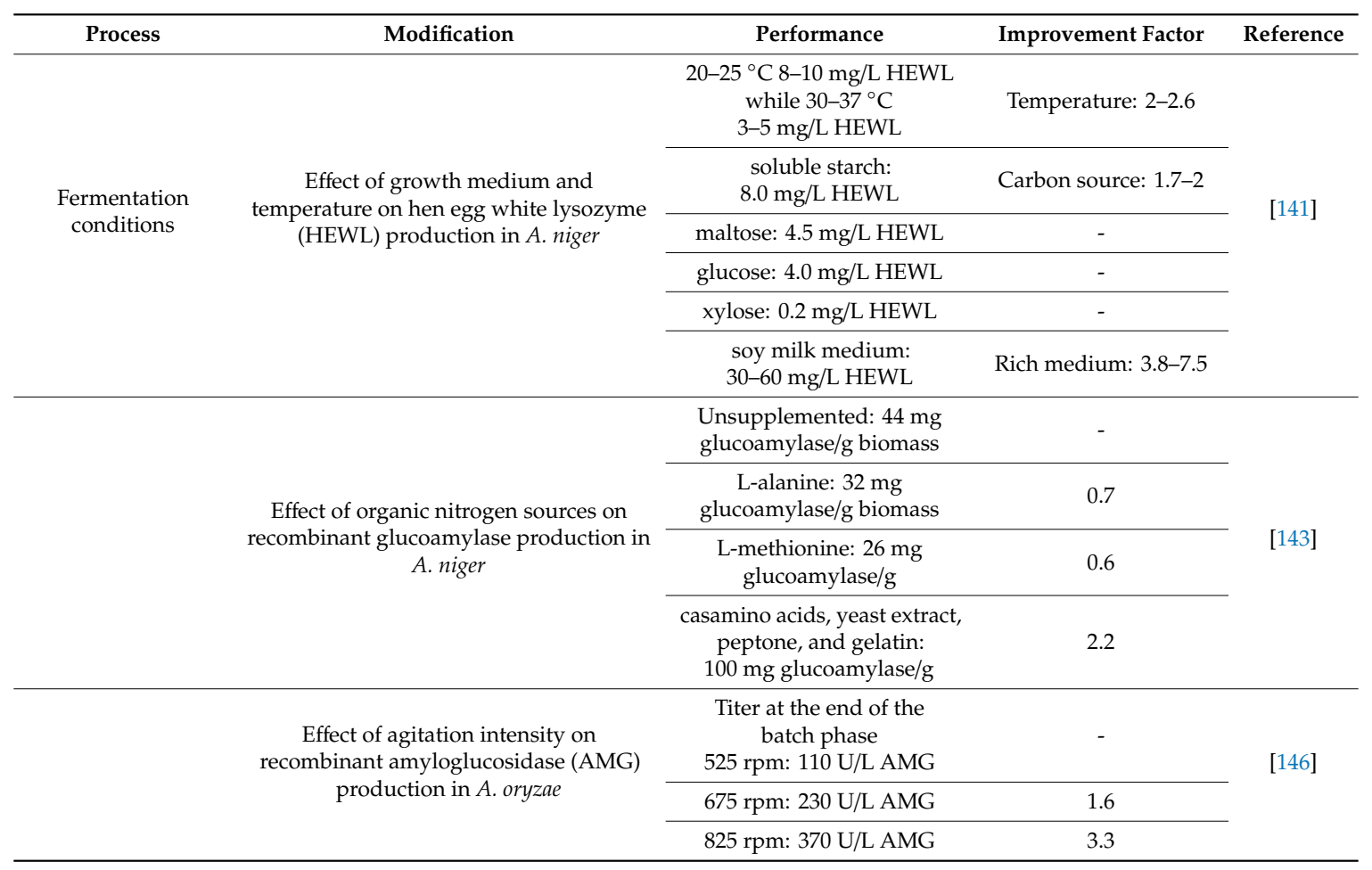


Table 12. Cont.

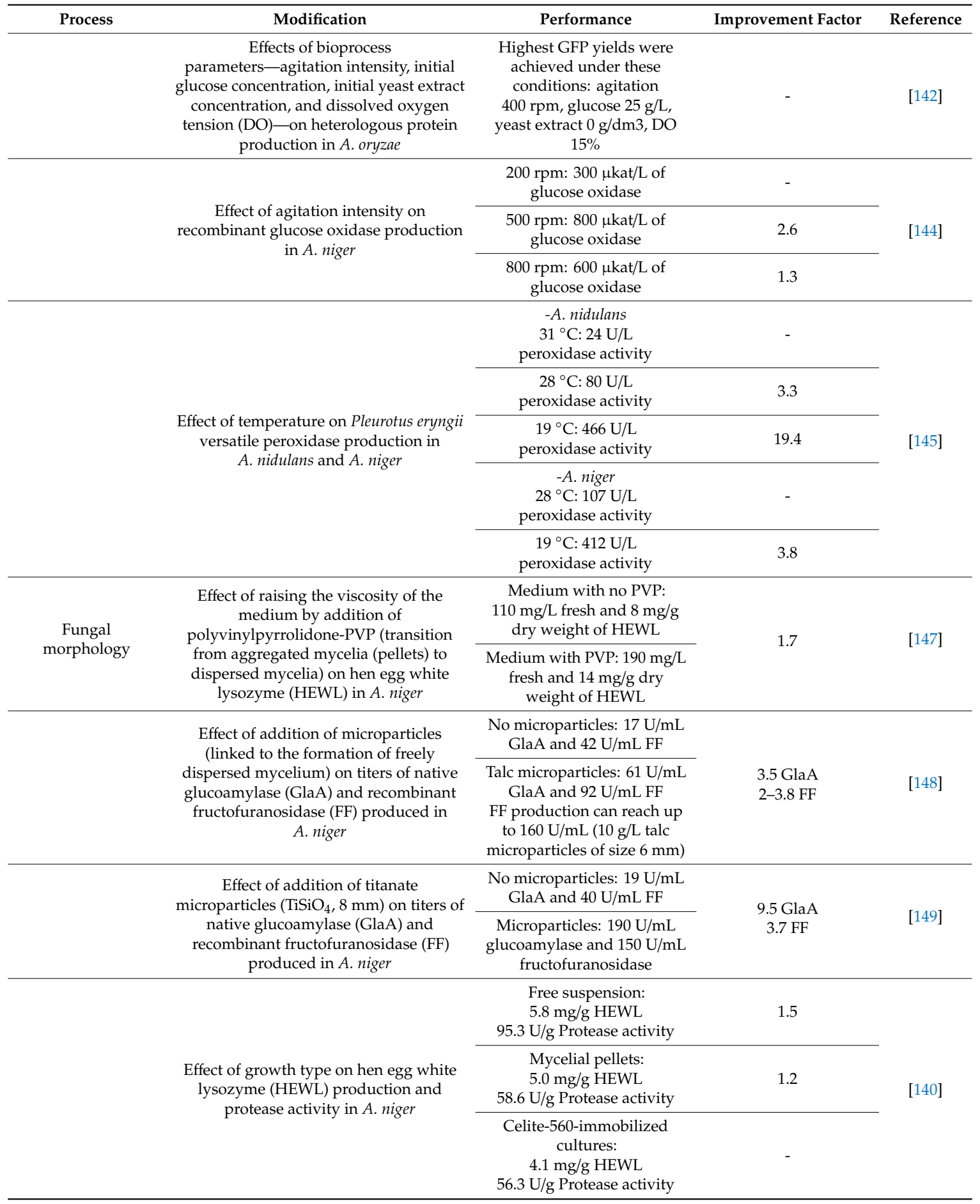

Additional bioprocess parameters such as agitation intensity, initial nutrient concentration and dissolved oxygen levels were also studied with regard to heterologous protein production in different Aspergillus fermentation types [142,146].

\subsection{Altering Fungal Morphology Using Bioprocessing}

Filamentous fungi that grow in submerged cultures, including aspergilli, exhibit variable morphologies, which can affect the overall performance of the microorganism during fermentation. The commonly observed filamentous growth results in undesirable viscous cultures, which require 
high consumption of energy for agitation and usually complicate downstream processing. On the contrary, a pelleted morphology (growth in pellets) decreases viscosity of the culture, improves mixing, and facilitates downstream processing. However, when large pellets are formed in the culture, diffusion of oxygen and nutrients to the inner pellet core is hindered, resulting in reduced productivity [135].

Many studies have attempted to correlate high protein production yields to a specific type of fungal morphology. For A. niger, dispersed mycelial suspensions led to higher protein yields over the pelleted form [140] (Table 12). In fact, microparticles are often added into Aspergillus cultures in order to prevent formation of large pellets and to favor formation of disperse mycelium, and consequently recombinant protein production [144,147-149]. However, Gyamerah et al. (2002) showed that the free suspension culture presented a higher protease activity, compared to the cultures with immobilized fungal biomass (mycelial pellet or by entrapment in Celite beads), and this could be an additional limitation for recombinant protein production [140].

\section{Conclusions and Future Perspectives}

Filamentous fungi hold unlimited potential for industrial applications, from the development of meat-like products and biomaterials, to bioremediation and biofuel production. One of their best qualities, largely exploited by the industry, is their innate capacity for the secretion of enzymes, which facilitate downstream processing and product recovery. Moreover, their ability to produce complex proteins with post-translational modifications and the fact that they can be cultivated on inexpensive media makes them a promising alternative for production of eukaryotic proteins. Despite their undeniable potential though, filamentous fungi have not yet been exploited to the fullest in the industrial production of recombinant proteins.

Advances in the molecular toolkit available for genetic manipulation of several Aspergillus species opened up the path for developing them into production systems for recombinant proteins. Nevertheless, due to a number of factors described in the review, aspergilli have not yet met the expected production levels. Many studies that focused on engineering different steps of protein synthesis and secretion, or generating protease-deficient strains, have resulted in a significant increase of protein yields. Additionally, optimization of the fungal fermentation process has further improved protein production. However, there are aspects of the fungal physiology that limit protein production and remain unclear. Continuous data input from "omics" studies sheds light on the complex fungal mechanisms related to protein quality control and secretion stress, as well as their impact on protein productivity. The knowledge generated from these studies combined with advances in the field of synthetic biology will soon place Aspergillus, and possibly other filamentous fungi, in the race for the most efficient recombinant protein production system. Its potential as a large-scale production platform not only for recombinant proteins, but also for organic acids, bioactive compounds, enzymes, and peptides, as well as new perspectives related to the use of Aspergillus in waste treatment and bioremediation processes, prove that this fungus can provide sustainable solutions for multiple and diverse markets and industries.

Author Contributions: Conceptualization, F.N. and R.F.; writing-original draft preparation, F.N. and R.F.; writing—review—editing, F.N., U.H.M.; C.S. and R.F. supervision, C.S. and R.F.; project administration, C.S.; funding acquisition, C.S. and R.F. All authors have read and agreed to the published version of the manuscript.

Funding: FN's post-doctorate is supported through the project "PEPTIPORTE-Peptide production and robust export" funded by Région Hauts-de-France and Bpifrance (FRRI Hauts-de-France), grant number DOS0080512. Publication fee was partly funded by the Université de Picardie Jules Verne.

Conflicts of Interest: The authors declare no conflict of interest. The funders had no role in the design of the study; in the collection, analyses, or interpretation of data; in the writing of the manuscript; or in the decision to publish the results. 


\section{References}

1. Puetz, J.; Wurm, F.M. Recombinant proteins for industrial versus pharmaceutical purposes: A review of process and pricing. Processes 2019, 7, 476. [CrossRef]

2. Choi, J.-M.; Han, S.-S.; Kim, H.-S. Industrial applications of enzyme biocatalysis: Current status and future aspects. Biotechnol. Adv. 2015, 33, 1443-1454. [CrossRef] [PubMed]

3. Baeshen, N.A.; Baeshen, M.N.; Sheikh, A.; Bora, R.S.; Ahmed, M.M.M.; Ramadan, H.A.I.; Saini, K.S.; Redwan, E.M. Cell factories for insulin production. Microb. Cell Fact. 2014, 13, 141. [CrossRef]

4. Khan, S.; Ullah, M.W.; Siddique, R.; Nabi, G.; Manan, S.; Yousaf, M.; Hou, H. Role of recombinant DNA technology to improve life. Int. J. Genomics 2016, 2016, 1-14. [CrossRef] [PubMed]

5. Walsh, G. Biopharmaceutical benchmarks 2018. Nat. Biotechnol. 2018, 36, 1136-1145. [CrossRef] [PubMed]

6. Ferreira, R.d.G.; Azzoni, A.R.; Freitas, S. Techno-economic analysis of the industrial production of a low-cost enzyme using E. coli: The case of recombinant $\beta$-glucosidase. Biotechnol. Biofuels 2018, 11, 81. [CrossRef]

7. Nevalainen, H.; Peterson, R. Making recombinant proteins in filamentous fungi-Are we expecting too much? Front. Microbiol. 2014, 5, 1-10. [CrossRef]

8. Demain, A.L.; Vaishnav, P. Production of recombinant proteins by microbes and higher organisms. Biotechnol. Adv. 2009, 27, 297-306. [CrossRef]

9. Baghban, R.; Farajnia, S.; Rajabibazl, M.; Ghasemi, Y.; Mafi, A.; Hoseinpoor, R.; Rahbarnia, L.; Aria, M. Yeast expression systems: Overview and recent advances. Mol. Biotechnol. 2019, 61, 365-384. [CrossRef]

10. Xie, Y.; Han, X.; Miao, Y. An effective recombinant protein expression and purification system in Saccharomyces cerevisiae. Curr. Protoc. Mol. Biol. 2018, 123, e62. [CrossRef]

11. Meyer, V.; Basenko, E.Y.; Benz, J.P.; Braus, G.H.; Caddick, M.X.; Csukai, M.; de Vries, R.P.; Endy, D.; Frisvad, J.C.; Gunde-Cimerman, N.; et al. Growing a circular economy with fungal biotechnology: A white paper. Fungal Biol. Biotechnol. 2020, 7, 5. [CrossRef] [PubMed]

12. Havlik, D.; Brandt, U.; Bohle, K.; Fleißner, A. Establishment of Neurospora crassa as a host for heterologous protein production using a human antibody fragment as a model product. Microb. Cell Fact. 2017, 16, 128. [CrossRef] [PubMed]

13. Landowski, C.P.; Mustalahti, E.; Wahl, R.; Croute, L.; Sivasiddarthan, D.; Westerholm-Parvinen, A.; Sommer, B.; Ostermeier, C.; Helk, B.; Saarinen, J.; et al. Enabling low cost biopharmaceuticals: High level interferon alpha-2b production in Trichoderma reesei. Microb. Cell Fact. 2016, 15, 104. [CrossRef]

14. Magaña-Ortíz, D.; Fernández, F.; Loske, A.M.; Gómez-Lim, M.A. Extracellular expression in Aspergillus niger of an antibody fused to Leishmania sp. antigens. Curr. Microbiol. 2018, 75, 40-48. [CrossRef]

15. Arnau, J.; Yaver, D.; Hjort, C.M. Strategies and challenges for the development of industrial enzymes using fungal cell factories. In Grand Challenges in Fungal Biotechnology; Springer: Cham, Switzerland, 2020; pp. 179-210, ISBN 9783030295417.

16. Sun, X.; Su, X. Harnessing the knowledge of protein secretion for enhanced protein production in filamentous fungi. World J. Microbiol. Biotechnol. 2019, 35, 54. [CrossRef] [PubMed]

17. Meyer, V. Genetic engineering of filamentous fungi-Progress, obstacles and future trends. Biotechnol. Adv. 2008, 26, 177-185. [CrossRef] [PubMed]

18. Gupta, S.K.; Shukla, P. Advanced technologies for improved expression of recombinant proteins in bacteria: Perspectives and applications. Crit. Rev. Biotechnol. 2016, 36, 1089-1098. [CrossRef]

19. Baeshen, M.N.; Al-Hejin, A.M.; Bora, R.S.; Ahmed, M.M.M.; Ramadan, H.A.I.; Saini, K.S.; Baeshen, N.A.; Redwan, E.M. Production of biopharmaceuticals in E. coli: Current scenario and future perspectives. J. Microbiol. Biotechnol. 2015, 25, 953-962. [CrossRef]

20. Contreras-Gómez, A.; Sánchez-Mirón, A.; García-Camacho, F.; Molina-Grima, E.; Chisti, Y. Protein production using the baculovirus-insect cell expression system. Biotechnol. Prog. 2014, 30, 1-18. [CrossRef]

21. Hunter, M.; Yuan, P.; Vavilala, D.; Fox, M. Optimization of protein expression in mammalian cells. Curr. Protoc. Protein Sci. 2019, 95, e77. [CrossRef]

22. Houdebine, L.-M. Production of pharmaceutical proteins by transgenic animals. Comp. Immunol. Microbiol. Infect. Dis. 2009, 32, 107-121. [CrossRef]

23. Łojewska, E.; Kowalczyk, T.; Olejniczak, S.; Sakowicz, T. Extraction and purification methods in downstream processing of plant-based recombinant proteins. Protein Expr. Purif. 2016, 120, 110-117. [CrossRef] [PubMed] 
24. Yao, J.; Weng, Y.; Dickey, A.; Wang, K. Plants as factories for human pharmaceuticals: Applications and challenges. Int. J. Mol. Sci. 2015, 16, 28549-28565. [CrossRef]

25. Currie, J.N. The citric acid fermentation of Aspergillus niger. J. Biol. Chem. 1917, 31, 15-37.

26. Cairns, T.C.; Nai, C.; Meyer, V. How a fungus shapes biotechnology: 100 years of Aspergillus niger research. Fungal Biol. Biotechnol. 2018, 5, 13. [CrossRef]

27. Dai, Z.; Zhou, H.; Zhang, S.; Gu, H.; Yang, Q.; Zhang, W.; Dong, W.; Ma, J.; Fang, Y.; Jiang, M.; et al. Current advance in biological production of malic acid using wild type and metabolic engineered strains. Bioresour. Technol. 2018, 258, 345-353. [CrossRef] [PubMed]

28. Barrios-González, J.; Miranda, R.U. Biotechnological production and applications of statins. Appl. Microbiol. Biotechnol. 2010, 85, 869-883. [CrossRef]

29. Meyer, V.; Andersen, M.R.; Brakhage, A.A.; Braus, G.H.; Caddick, M.X.; Cairns, T.C.; de Vries, R.P.; Haarmann, T.; Hansen, K.; Hertz-Fowler, C.; et al. Current challenges of research on filamentous fungi in relation to human welfare and a sustainable bio-economy: A white paper. Fungal Biol. Biotechnol. 2016, 3, 6. [CrossRef] [PubMed]

30. Martins-Santana, L.; Nora, L.C.; Sanches-Medeiros, A.; Lovate, G.L.; Cassiano, M.H.A.; Silva-Rocha, R. Systems and synthetic biology approaches to engineer fungi for fine chemical production. Front. Bioeng. Biotechnol. 2018, 6, 117. [CrossRef]

31. Meyer, V.; Wu, B.; Ram, A.F.J. Aspergillus as a multi-purpose cell factory: Current status and perspectives. Biotechnol. Lett. 2011, 33, 469-476. [CrossRef]

32. Leynaud-Kieffer, L.M.C.; Curran, S.C.; Kim, I.; Magnuson, J.K.; Gladden, J.M.; Baker, S.E.; Simmons, B.A. A new approach to Cas9-based genome editing in Aspergillus niger that is precise, efficient and selectable. PLoS ONE 2019, 14, e0210243. [CrossRef] [PubMed]

33. Sarkari, P.; Marx, H.; Blumhoff, M.L.; Mattanovich, D.; Sauer, M.; Steiger, M.G. An efficient tool for metabolic pathway construction and gene integration for Aspergillus niger. Bioresour. Technol. 2017, 245, 1327-1333. [CrossRef] [PubMed]

34. Cairns, T.C.; Feurstein, C.; Zheng, X.; Zhang, L.H.; Zheng, P.; Sun, J.; Meyer, V. Functional exploration of co-expression networks identifies a nexus for modulating protein and citric acid titres in Aspergillus niger submerged culture. Fungal Biol. Biotechnol. 2019, 6, 18. [CrossRef]

35. Nødvig, C.S.; Nielsen, J.B.; Kogle, M.E.; Mortensen, U.H. A CRISPR-Cas9 system for genetic engineering of filamentous fungi. PLoS ONE 2015, 10, e0133085. [CrossRef] [PubMed]

36. Katayama, T.; Tanaka, Y.; Okabe, T.; Nakamura, H.; Fujii, W.; Kitamoto, K.; Maruyama, J.I. Development of a genome editing technique using the CRISPR/Cas9 system in the industrial filamentous fungus Aspergillus oryzae. Biotechnol. Lett. 2016, 38, 637-642. [CrossRef] [PubMed]

37. Fuller, K.K.; Chen, S.; Loros, J.J.; Dunlap, J.C. Development of the CRISPR/Cas9 system for targeted gene disruption in Aspergillus fumigatus. Eukaryot. Cell 2015, 14, 1073-1080. [CrossRef] [PubMed]

38. Dunn-Coleman, N.S.; Bloebaum, P.; Berka, R.M.; Bodie, E.; Robinson, N.; Armstrong, G.; Ward, M.; Przetak, M.; Carter, G.L.; LaCost, R.; et al. Commercial levels of chymosin production by Aspergillus. Bio/Technology 1991, 9, 976-981. [CrossRef]

39. Ward, P.P.; Lo, J.-Y.; Duke, M.; May, G.S.; Headon, D.R.; Conneely, O.M. Production of biologically active recombinant human lactoferrin in Aspergillus Oryzae. Nat. Biotechnol. 1992, 10, 784-789. [CrossRef] [PubMed]

40. Nakajima, K.I.; Asakura, T.; Maruyama, J.I.; Morita, Y.; Oike, H.; Shimizu-Ibuka, A.; Misaka, T.; Sorimachi, H.; Arai, S.; Kitamoto, K.; et al. Extracellular production of neoculin, a sweet-tasting heterodimeric protein with taste-modifying activity, by Aspergillus oryzae. Appl. Environ. Microbiol. 2006, 72, 3716-3723. [CrossRef] [PubMed]

41. Van Den Hondel, C.A.M.J.J.; Punt, P.J.; Van Gorcom, R.F.M. Heterologous Gene Expression in Filamentous Fungi; Academic Press, Inc.: Cambridge, MA, USA, 1991.

42. Fleißner, A.; Dersch, P. Expression and export: Recombinant protein production systems for Aspergillus. Appl. Microbiol. Biotechnol. 2010, 87, 1255-1270. [CrossRef] [PubMed]

43. Rendsvig, J.K.H.; Workman, C.T.; Hoof, J.B. Bidirectional histone-gene promoters in Aspergillus: Characterization and application for multi-gene expression. Fungal Biol. Biotechnol. 2019, 6, 24. [CrossRef] [PubMed]

44. Qiu, R.; Zhu, X.; Liu, L.; Tang, G. Detection of a protein, AngCP, which binds specifically to the three upstream regions of glaA gene in A. niger T21. Sci. China Ser. C 2002, 45, 527. [CrossRef] [PubMed] 
45. Liu, L.; Liu, J.; Qiu, R.X.; Zhu, X.G.; Dong, Z.Y.; Tang, G.M. Improving heterologous gene expression in Aspergillus niger by introducing multiple copies of protein-binding sequence containing CCAAT to the promoter. Lett. Appl. Microbiol. 2003, 36, 358-361. [CrossRef]

46. Moralejo, F.-J.; Cardoza, R.-E.; Gutierrez, S.; Martin, J.F. Thaumatin production in Aspergillus awamori by use of expression cassettes with strong fungal promoters and high gene dosage. Appl. Environ. Microbiol. 1999, 65, 1168-1174. [CrossRef]

47. Pachlinger, R.; Mitterbauer, R.; Adam, G.; Strauss, J. Metabolically independent and accurately adjustable Aspergillus sp. expression system. Appl. Environ. Microbiol. 2005, 71, 672-678. [CrossRef] [PubMed]

48. Bando, H.; Hisada, H.; Ishida, H.; Hata, Y.; Katakura, Y.; Kondo, A. Isolation of a novel promoter for efficient protein expression by Aspergillus oryzae in solid-state culture. Appl. Microbiol. Biotechnol. 2011, 92, 561-569. [CrossRef] [PubMed]

49. Gressler, M.; Hortschansky, P.; Geib, E.; Brock, M. A new high-performance heterologous fungal expression system based on regulatory elements from the Aspergillus terreus terrein gene cluster. Front. Microbiol. 2015, 6. [CrossRef]

50. Jun, W.; Yuk, S.L. Polynucleotide Fragment, Expression Vector Comprising Same, Aspergillus niger Genetic Engineering Strain and Application of Aspergillus niger Genetic Engineering. CN Patent No. CN107304431A, 31 October 2017.

51. Li, W.; Yu, J.; Li, Z.; Yin, W.B. Rational design for fungal laccase production in the model host Aspergillus nidulans. Sci. China Life Sci. 2019, 62, 84-94. [CrossRef]

52. Yin, W.; Li, W.; Ma, Z. Construction and Application of Heterologous Expression System of Aspergillus nidulans. CN Patent No. CN108795970A, 13 November 2018.

53. Li, M.; Lu, F.; Chen, Y. Fungus Promoter and Application Thereof 2019. CN Patent No. CN110331144A, 15 October 2019.

54. Gladden, J.M.; Campen, S.A.; Zhang, J.; Magnuson, J.K.; Baker, S.E.; Simmons, B.A. Promoter Useful for High Expression of a Heterologous Gene of Interest in Aspergillus niger. U.S. Patent No. US20,190,169,584A1, 6 June 2019.

55. Meyer, V.; Wanka, F.; van Gent, J.; Arentshorst, M.; van den Hondel, C.A.M.J.J.; Ram, A.F.J. Fungal gene expression on demand: An inducible, tunable, and metabolism-independent expression system for Aspergillus niger. Appl. Environ. Microbiol. 2011, 77, 2975-2983. [CrossRef]

56. Vogt, K.; Bhabhra, R.; Rhodes, J.C.; Askew, D.S. Doxycycline-regulated gene expression in the opportunistic fungal pathogen Aspergillus fumigatus. BMC Microbiol. 2005, 5, 1-11. [CrossRef] [PubMed]

57. Rantasalo, A.; Landowski, C.P.; Kuivanen, J.; Korppoo, A.; Reuter, L.; Koivistoinen, O.; Valkonen, M.; Penttilä, M.; Jäntti, J.; Mojzita, D. A universal gene expression system for fungi. Nucleic Acids Res. 2018, 46, e111. [CrossRef] [PubMed]

58. Verdoes, J.C.; Punt, P.J.; Schrickx, J.M.; van Verseveld, H.W.; Stouthamer, A.H.; van den Hondel, C.A.M.J.J. Glucoamylase overexpression in Aspergillus niger: Molecular genetic analysis of strains containing multiple copies of the glaA gene. Transgenic Res. 1993, 2, 84-92. [CrossRef] [PubMed]

59. Wallis, G.L.F.; Swift, R.J.; Hemming, F.W.; Trinci, A.P.J.; Peberdy, J.F. Glucoamylase overexpression and secretion in Aspergillus niger: Analysis of glycosylation. Biochim. Biophys. Acta 1999, 1472, 576-586. [CrossRef]

60. Tada, S.; Iimura, Y.; Gomi, K.; Takahashi, K.; Hara, S.; Yoshizawa, K. Cloning and nucleotide sequence of the genomic taka-amylase a gene of Aspergillus oryzae. Agric. Biol. Chem. 1989, 53, 593-599. [CrossRef]

61. Schalén, M.; Anyaogu, D.C.; Hoof, J.B.; Workman, M. Effect of secretory pathway gene overexpression on secretion of a fluorescent reporter protein in Aspergillus nidulans. Fungal Biol. Biotechnol. 2016, 3, 1-14. [CrossRef]

62. Lubertozzi, D.; Keasling, J.D. Marker and promoter effects on heterologous expression in Aspergillus nidulans. Appl. Microbiol. Biotechnol. 2006, 72, 1014-1023. [CrossRef]

63. Verdoes, J.C.; Punt, P.J.; van den Hondel, C.A.M.J.J. Molecular genetic strain improvement for the overproduction of fungal proteins by filamentous fungi. Appl. Microbiol. Biotechnol. 1995, 43, 195-205. [CrossRef]

64. Gouka, R.J.; Hessing, J.G.M.; Stam, H.; Musters, W.; van den Hondel, C.A.M.J.J. A novel strategy for the isolation of defined pyrG mutants and the development of a site-specific integration system for Aspergillus awamori. Curr. Genet. 1995, 27, 536-540. [CrossRef] 
65. Qin, L.; Jiang, X.; Dong, Z.; Huang, J.; Chen, X. Identification of two integration sites in favor of transgene expression in Trichoderma reesei. Biotechnol. Biofuels 2018, 11, 142. [CrossRef]

66. Hansen, B.G.; Salomonsen, B.; Nielsen, M.T.; Nielsen, J.B.; Hansen, N.B.; Nielsen, K.F.; Regueira, T.B.; Nielsen, J.; Patil, K.R.; Mortensen, U.H. Versatile enzyme expression and characterization system for Aspergillus nidulans, with the Penicillium brevicompactum polyketide synthase gene from the mycophenolic acid gene cluster as a test case. Appl. Environ. Microbiol. 2011, 77, 3044-3051. [CrossRef]

67. Mauro, V.P. Codon optimization in the production of recombinant biotherapeutics: Potential risks and considerations. BioDrugs 2018, 32, 69-81. [CrossRef] [PubMed]

68. Gustafsson, C.; Minshull, J.; Govindarajan, S.; Ness, J.; Villalobos, A.; Welch, M. Engineering genes for predictable protein expression. Protein Expr. Purif. 2012, 83, 37-46. [CrossRef] [PubMed]

69. Tanaka, M.; Tokuoka, M.; Gomi, K. Effects of codon optimization on the mRNA levels of heterologous genes in filamentous fungi. Appl. Microbiol. Biotechnol. 2014, 98, 3859-3867. [CrossRef] [PubMed]

70. Tokuoka, M.; Tanaka, M.; Ono, K.; Takagi, S.; Shintani, T.; Gomi, K. Codon optimization increases steady-state mRNA levels in Aspergillus oryzae heterologous gene expression. Appl. Environ. Microbiol. 2008, 74, 6538-6546. [CrossRef]

71. Koda, A.; Bogaki, T.; Minetoki, T.; Hirotsune, M. High expression of a synthetic gene encoding potato

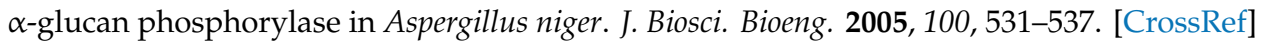

72. Gouka, R.J.; Punt, P.J.; Hessing, J.G.M.; Van Den Hondel, C.A.M.J.J. Analysis of heterologous protein production in defined recombinant Aspergillus awamori strains. Appl. Environ. Microbiol. 1996, 62, 1951-1957. [CrossRef]

73. Tanaka, M.; Tokuoka, M.; Shintani, T.; Gomi, K. Transcripts of a heterologous gene encoding mite allergen Der $\mathrm{f} 7$ are stabilized by codon optimization in Aspergillus oryzae. Appl. Microbiol. Biotechnol. 2012, 96, 1275-1282. [CrossRef]

74. Yu, C.-H.; Dang, Y.; Zhou, Z.; Wu, C.; Zhao, F.; Sachs, M.S.; Liu, Y. Codon usage influences the local rate of translation elongation to regulate co-translational protein folding. Mol. Cell 2015, 59, 744-754. [CrossRef]

75. Gouka, R.J.; Punt, P.J.; Van Den Hondel, C.A.M.J.J. Glucoamylase gene fusions alleviate limitations for protein production in Aspergillus awamori at the transcriptional and (post)translational levels. Appl. Environ. Microbiol. 1997, 63, 488-497. [CrossRef]

76. Carraway, K.L.; Hull, S.R. O-glycosylation pathway for mucin-type glycoproteins. BioEssays 1989, 10, $117-121$. [CrossRef]

77. Bause, E. Structural requirements of N-glycosylation of proteins. Studies with proline peptides as conformational probes. Biochem. J. 1983, 209, 331-336. [CrossRef] [PubMed]

78. Deshpande, N.; Wilkins, M.R.; Packer, N.; Nevalainen, H. Protein glycosylation pathways in filamentous fungi. Glycobiology 2008, 18, 626-637. [CrossRef] [PubMed]

79. Eriksen, S.H.; Jensen, B.; Olsen, J. Effect of N-linked glycosylation on secretion, activity, and stability of $\alpha$-amylase from Aspergillus oryzae. Curr. Microbiol. 1998, 37, 117-122. [CrossRef] [PubMed]

80. Maras, M.; van Die, I.; Contreras, R.; van den Hondel, C.A. Filamentous fungi as production organisms for glycoproteins of bio-medical interest. Glycoconj. J. 1999, 16, 99-107. [CrossRef] [PubMed]

81. Kainz, E.; Gallmetzer, A.; Hatzl, C.; Nett, J.H.; Li, H.; Schinko, T.; Pachlinger, R.; Berger, H.; Reyes-Dominguez, Y.; Bernreiter, A.; et al. N-Glycan modification in Aspergillus species. Appl. Environ. Microbiol. 2008, 74, 1076-1086. [CrossRef]

82. Kasajima, Y.; Yamaguchi, M.; Hirai, N.; Ohmachi, T.; Yoshida, T. In vivo expression of UDP-N-acetylglucosamine: Alpha-3-D-mannoside beta-1,2-N-acetylglucosaminyltransferase I (GnT-1) in Aspergillus oryzae and effects on the sugar chain of alpha-amylase. Biosci. Biotechnol. Biochem. 2006, 70, 2662-2668. [CrossRef]

83. Ichishima, E.; Taya, N.; Ikeguchi, M.; Chiba, Y.; Nakamura, M.; Kawabata, C.; Inoue, T.; Takahashi, K.; Minetoki, T.; Ozeki, K.; et al. Molecular and enzymic properties of recombinant 1, 2-alpha-mannosidase from Aspergillus saitoi overexpressed in Aspergillus oryzae cells. Biochem. J. 1999, 339, 589-597. [CrossRef]

84. Kalsner, I.; Hintz, W.; Reid, L.S.; Schachter, H. Insertion into Aspergillus nidulans of functional UDP-GlcNAc: Alpha 3-D- mannoside beta-1,2-N-acetylglucosaminyl-transferase I, the enzyme catalysing the first committed step from oligomannose to hybrid and complex N-glycans. Glycoconj. J. 1995, 12, 360-370. [CrossRef] 
85. Guillemette, T.; van Peij, N.N.M.E.; Goosen, T.; Lanthaler, K.; Robson, G.D.; van den Hondel, C.A.M.J.J.; Stam, H.; Archer, D.B. Genomic analysis of the secretion stress response in the enzyme-producing cell factory Aspergillus niger. BMC Genom. 2007, 8, 158. [CrossRef]

86. Kwon, M.J.; Jørgensen, T.R.; Nitsche, B.M.; Arentshorst, M.; Park, J.; Ram, A.F.; Meyer, V. The transcriptomic fingerprint of glucoamylase over-expression in Aspergillus niger. BMC Genom. 2012, 13, 701. [CrossRef]

87. Geysens, S.; Whyteside, G.; Archer, D.B. Genomics of protein folding in the endoplasmic reticulum, secretion stress and glycosylation in the aspergilli. Fungal Genet. Biol. 2009, 46, S121-S140. [CrossRef]

88. Valkonen, M.; Ward, M.; Wang, H.; Penttilä, M.; Saloheimo, M. Improvement of foreign-protein production in Aspergillus niger var. awamori by constitutive induction of the unfolded-protein response. Appl. Environ. Microbiol. 2003, 69, 6979-6986. [CrossRef] [PubMed]

89. Derkx, P.M.F.; Madrid, S.M. Peptidyl prolyl cis-trans isomerases 2000. World Patent WO0018934, 6 April 2000.

90. Wang, H.; Ward, M. Molecular characterization of a PDI-related gene prpA in Aspergillus niger var. awamori. Curr. Genet. 2000, 37, 57-64. [CrossRef]

91. Moralejo, F.; Watson, A.; Jeenes, D.; Archer, D.; Martín, J. A defined level of protein disulfide isomerase expression is required for optimal secretion of thaumatin by Aspergillus awamori. Mol. Genet. Genom. 2001, 266, 246-253. [CrossRef] [PubMed]

92. Conesa, A.; Jeenes, D.; Archer, D.B.; van den Hondel, C.A.; Punt, P.J. Calnexin overexpression increases manganese peroxidase production in Aspergillus niger. Appl. Environ. Microbiol. 2002, 68, 846-851. [CrossRef] [PubMed]

93. Lombraña, M.; Moralejo, F.J.; Pinto, R.; Martín, J.F. Modulation of Aspergillus awamori thaumatin secretion by modification of bipA gene expression. Appl. Environ. Microbiol. 2004, 70, 5145-5152. [CrossRef]

94. Banerjee, S.; Vishwanath, P.; Cui, J.; Kelleher, D.J.; Gilmore, R.; Robbins, P.W.; Samuelson, J. The evolution of $\mathrm{N}$-glycan-dependent endoplasmic reticulum quality control factors for glycoprotein folding and degradation. Proc. Natl. Acad. Sci. USA 2007, 104, 11676-11681. [CrossRef]

95. Zhang, L.; Feng, D.; Fang, W.; Ouyang, H.; Luo, Y.; Du, T.; Jin, C. Comparative proteomic analysis of an Aspergillus fumigatus mutant deficient in glucosidase I (AfCwh41). Microbiology 2009, 155, 2157-2167. [CrossRef]

96. Ríos, S.; Fernández-Monistrol, I.; Laborda, F. Effect of tunicamycin on $\alpha$-galactosidase secretion by Aspergillus nidulans and the importance of N-glycosylation. FEMS Microbiol. Lett. 1994, 120, 169-175. [CrossRef]

97. Perlińska-lenart, U.; Kurzatkowski, W.; Janas, P.; Palamarczyk, G.; Kruszewska, J.S. Protein production and secretion in an Aspergillus nidulans mutant impaired in glycosylation. Acta Biochim. Pol. 2005, 52, 195-205. [CrossRef]

98. Van den Brink, H.J.M.; Petersen, S.G.; Rahbek-Nielsen, H.; Hellmuth, K.; Harboe, M. Increased production of chymosin by glycosylation. J. Biotechnol. 2006, 125, 304-310. [CrossRef] [PubMed]

99. Wang, H. Gene Inactivated Mutants with Altered Protein Production. World Patent No. WO2006110677, 19 October 2006.

100. Dai, Z.; Aryal, U.K.; Shukla, A.; Qian, W.J.; Smith, R.D.; Magnuson, J.K.; Adney, W.S.; Beckham, G.T.; Brunecky, R.; Himmel, M.E.; et al. Impact of alg3 gene deletion on growth, development, pigment production, protein secretion, and functions of recombinant Trichoderma reesei cellobiohydrolases in Aspergillus niger. Fungal Genet. Biol. 2013, 61, 120-132. [CrossRef] [PubMed]

101. Pantazopoulou, A. The Golgi apparatus: Insights from filamentous fungi. Mycologia 2016, 108, $603-622$. [CrossRef] [PubMed]

102. Fiedler, M.R.M.; Barthel, L.; Kubisch, C.; Nai, C.; Meyer, V. Construction of an improved Aspergillus niger platform for enhanced glucoamylase secretion. Microb. Cell Fact. 2018, 17, 1-12. [CrossRef]

103. Fiedler, M.R.M.; Cairns, T.C.; Koch, O.; Kubisch, C.; Meyer, V. Conditional expression of the small GTPase ArfA impacts secretion, morphology, growth, and actin ring position in Aspergillus niger. Front. Microbiol. 2018, 9, 1-17. [CrossRef]

104. Hoang, H.-D.; Maruyama, J.; Kitamoto, K. Modulating endoplasmic reticulum-golgi cargo receptors for improving secretion of carrier-fused heterologous proteins in the filamentous fungus Aspergillus oryzae. Appl. Environ. Microbiol. 2015, 81, 533-543. [CrossRef]

105. Bonifacino, J.S.; Weissman, A.M. Ubiquitin and the control of protein fate in the secretory and endocytic pathways. Annu. Rev. Cell Dev. Biol. 1998, 14, 19-57. [CrossRef] 
106. Jacobs, D.I.; Olsthoorn, M.M.A.; Maillet, I.; Akeroyd, M.; Breestraat, S.; Donkers, S.; van der Hoeven, R.A.M.; van den Hondel, C.A.M.J.J.; Kooistra, R.; Lapointe, T. Effective lead selection for improved protein production in Aspergillus niger based on integrated genomics. Fungal Genet. Biol. 2009, 46, S141-S152. [CrossRef]

107. Carvalho, N.D.S.P.; Arentshorst, M.; Kooistra, R.; Stam, H.; Sagt, C.M.; Van Den Hondel, C.A.M.J.J.; Ram, A.F.J. Effects of a defective ERAD pathway on growth and heterologous protein production in Aspergillus niger. Appl. Microbiol. Biotechnol. 2011, 89, 357-373. [CrossRef]

108. Yoon, J.; Aishan, T.; Maruyama, J.; Kitamoto, K. Enhanced production and secretion of heterologous proteins by the filamentous fungus Aspergillus oryzae via disruption of vacuolar protein sorting receptor gene Aovps10. Appl. Environ. Microbiol. 2010, 76, 5718-5727. [CrossRef]

109. Yoon, J.; Kikuma, T.; Maruyama, J.; Kitamoto, K. Enhanced production of bovine chymosin by autophagy deficiency in the filamentous fungus Aspergillus oryzae. PLoS ONE 2013, 8, e62512. [CrossRef] [PubMed]

110. Zhang, N.; An, Z. Heterologous protein expression in yeasts and filamentous fungi. In Manual of Industrial Microbiology and Biotechnology; Baltz, R.H., Demain, A.L., Davies, J.E., Bull, A.T., Junker, B., Katz, L., Lynd, L.R., Masurekar, P., Reeves, C.D., Zhao, H., Eds.; American Society of Microbiology Press: Washington, DC, USA, 2010; pp. 145-156, ISBN 9781555815127.

111. Lawlis, V.B. DNA Sequences, Vectors, and Fusion Polypeptides to Increase Secretion of Desired Polypeptides from Filamentous Fungi. World Patent No. WO9015860, 27 December 1990.

112. Ward, M.; Wilson, L.J.; Kodama, K.H.; Rey, M.W.; Berka, R.M. Improved production of chymosin in Aspergillus by expression as a glucoamylase-chymosin fusion. Nat. Biotechnol. 1990, 8, 435-440. [CrossRef] [PubMed]

113. Cullen, D.; Gray, G.L.; Wilson, L.J.; Hayenga, K.J.; Lamsa, M.H.; Rey, M.W.; Norton, S.; Berka, R.M. Controlled expression and secretion of bovine chymosin in Aspergillus nidulans. Nat. Biotechnol. 1987, 5, 369-376. [CrossRef]

114. Broekhuijsen, M.P.; Mattern, I.E.; Contreras, R.; Kinghorn, J.R.; van den Hondel, C.A.M.J.J. Secretion of heterologous proteins by Aspergillus niger: Production of active human interleukin-6 in a protease-deficient mutant by KEX2-like processing of a glucoamylase-hIL6 fusion protein. J. Biotechnol. 1993, 31, 135-145. [CrossRef]

115. Frenken, L.G.J.; Van Gorcom, R.F.M.; Hessing, J.G.M.; Van Den Hondel, C.A.; Musters, W.; Verbakel, J.M.A.; Verrips, C.T. Process for Producing Fusion Proteins Comprising Scfv Fragments by a Transformed Mould. World Patent No. WO9429457, 22 December 1994.

116. Ward, M.; Lin, C.; Victoria, D.C.; Fox, B.P.; Fox, J.A.; Wong, D.L.; Meerman, H.J.; Pucci, J.P.; Fong, R.B.; Heng, M.H.; et al. Characterization of humanized antibodies secreted by Aspergillus niger. Appl. Environ. Microbiol. 2004, 70, 2567-2576. [CrossRef]

117. Segato, F.; Damásio, A.R.L.; Gonçalves, T.A.; de Lucas, R.C.; Squina, F.M.; Decker, S.R.; Prade, R.A. High-yield secretion of multiple client proteins in Aspergillus. Enzyme Microb. Technol. 2012, 51, 100-106. [CrossRef] [PubMed]

118. Jin, F.J.; Watanabe, T.; Juvvadi, P.R.; Maruyama, J.; Arioka, M.; Kitamoto, K. Double disruption of the proteinase genes, tppA and pepE, increases the production level of human lysozyme by Aspergillus oryzae. Appl. Microbiol. Biotechnol. 2007, 76, 1059-1068. [CrossRef]

119. Ohno, A.; Maruyama, J.; Nemoto, T.; Arioka, M.; Kitamoto, K. A carrier fusion significantly induces unfolded protein response in heterologous protein production by Aspergillus oryzae. Appl. Microbiol. Biotechnol. 2011, 92, 1197-1206. [CrossRef]

120. Gouka, R.J.; Van Den Hondel, C.A.; Musters, W.; Stam, H.; Verbakel, J.M.A. Process for Producing/Secreting a Protein by a Transformed Mould Using Expression/Secretion Regulating Regions Derived from an Aspergillus Endoxylanase II Gene. World Patent No. WO9312237, 24 June 1993.

121. Jalving, R.; Van De Vondervoort, P.J.I.; Visser, J.; Schaap, P.J. Characterization of the Kexin-Like Maturase of Aspergillus niger. Appl. Environ. Microbiol. 2000, 66, 363-368. [CrossRef]

122. Wang, H.; Ward, M. Kex2 Cleavage Regions of Recombinant Fusion Proteins. U.S. Patent No. US8,936,917B2, 20 January 2015.

123. O’Donnell, D.; Wang, L.; Xu, J.; Ridgway, D.; Gu, T.; Moo-Young, M. Enhanced heterologous protein production in Aspergillus niger through $\mathrm{pH}$ control of extracellular protease activity. Biochem. Eng. J. 2001, 8, 187-193. [CrossRef] 
124. Van Den Hombergh, J.P.T.W.; Van De Vondervoort, P.J.I.; Fraissinet-Tachet, L.; Visser, J. Aspergillus as a host for heterologous protein production: The problem of proteases. Trends Biotechnol. 1997, 15, 256-263. [CrossRef]

125. Berka, R.M.; Ward, M.; Wilson, L.J.; Hayenga, K.J.; Kodama, K.H.; Carlomagne, L.P.; Thompson, S.A. Molecular cloning and deletion of the gene encoding aspergillopepsin A from Aspergillus awamori. Gene 1990, 86, 153-162. [CrossRef]

126. Mattern, I.E.; van Noort, J.M.; van den Berg, P.; Archer, D.B.; Roberts, I.N.; van den Hondep, C.A. Isolation and characterization of mutants of Aspergillus niger deficient in extracellular proteases. Mol. Gen. Genet. 1992, 332-336. [CrossRef]

127. Kamaruddin, N.; Storms, R.; Mahadi, N.M.; Illias, R.M.; Bakar, F.D.A.; Murad, A.M.A. Reduction of extracellular proteases increased activity and stability of heterologous protein in Aspergillus niger. Arab. J. Sci. Eng. 2018, 43, 3327-3338. [CrossRef]

128. Berka, R.M.; Hayenga, K.; Lawlis, V.B.; Ward, M. Aspartic Proteinase Deficient Filamentous Fungi. World Patent No. WO199000192, 11 January 1990.

129. Punt, P.J.; Schuren, F.H.J.; Lehmbeck, J.; Christensen, T.; Hjort, C.; van den Hondel, C.A.M.J.J. Characterization of the Aspergillus niger prtT, a unique regulator of extracellular protease encoding genes. Fungal Genet. Biol. 2008, 45, 1591-1599. [CrossRef]

130. Yoon, J.; Kimura, S.; Maruyama, J.; Kitamoto, K. Construction of quintuple protease gene disruptant for heterologous protein production in Aspergillus oryzae. Appl. Microbiol. Biotechnol. 2009, 82, 691-701. [CrossRef]

131. Yoon, J.; Maruyama, J.; Kitamoto, K. Disruption of ten protease genes in the filamentous fungus Aspergillus oryzae highly improves production of heterologous proteins. Appl. Microbiol. Biotechnol. 2011, 89, 747-759. [CrossRef] [PubMed]

132. Lehmbeck, J. Novel Host Cells and Methods of Producing Proteins. World Patent No. WO9812300, 26 March 1998.

133. Shinkawa, S.; Mitsuzawa, S.; Tanaka, M.; Imai, T. Aspergillus Mutant Strain and Transformant Thereof. U.S. Patent No. US9,567,563, 11 August 2016.

134. Taheri-Talesh, N.; Horio, T.; Araujo-Bazán, L.; Dou, X.; Espeso, E.A.; Peñalva, M.A.; Osmani, S.A.; Oakley, B.R. The tip growth apparatus of Aspergillus nidulans. Mol. Biol. Cell 2008, 19, 1439-1449. [CrossRef]

135. Grimm, L.H.; Kelly, S.; Krull, R.; Hempel, D.C. Morphology and productivity of filamentous fungi. Appl. Microbiol. Biotechnol. 2005, 69, 375-384. [CrossRef]

136. Sisniega, H.; Río, J.-L.; Amaya, M.-J.; Faus, I. Strategies for large-scale production of recombinant proteins in filamentous fungi. In Microbial Processes and Products; Humana Press: Totowa, NJ, USA, 2005; Volume 18, pp. 225-237.

137. El-Enshasy, H.A. Filamentous fungal cultures-Process characteristics, products, and applications. In Bioprocessing for Value-Added Products from Renewable Resources; Elsevier: Amsterdam, The Netherlands, 2007; pp. 225-261.

138. Workman, M.; Andersen, M.R.; Thykaer, J. Integrated approaches for assessment of cellular performance in industrially relevant filamentous fungi. Ind. Biotechnol. 2013, 9, 337-344. [CrossRef]

139. Wang, L.; Ridgway, D.; Gu, T.; Moo-Young, M. Bioprocessing strategies to improve heterologous protein production in filamentous fungal fermentations. Biotechnol. Adv. 2005, 23, 115-129. [CrossRef] [PubMed]

140. Gyamerah, M.; Merichetti, G.; Adedayo, O.; Scharer, J.; Moo-Young, M. Bioprocessing strategies for improving hen egg-white lysozyme (HEWL) production by recombinant Aspergillus niger HEWL WT-13-16. Appl. Microbiol. Biotechnol. 2002, 60, 403-407. [CrossRef] [PubMed]

141. MacKenzie, D.A.; Gendron, L.C.G.; Jeenes, D.J.; Archer, D.B. Physiological optimization of secreted protein production by Aspergillus niger. Enzyme Microb. Technol. 1994, 16, 276-280. [CrossRef]

142. Wang, L.; Ridgway, D.; Gu, T.; Moo-Young, M. Effects of process parameters on heterologous protein production in Aspergillus niger fermentation. J. Chem. Technol. Biotechnol. 2003, 78, 1259-1266. [CrossRef]

143. Swift, R.J.; Karandikar, A.; Griffen, A.M.; Punt, P.J.; van den Hondel, C.A.M.J.J.; Robson, G.D.; Trinci, A.P.J.; Wiebe, M.G. The Effect of organic nitrogen sources on recombinant glucoamylase production by Aspergillus niger in chemostat culture. Fungal Genet. Biol. 2000, 31, 125-133. [CrossRef] 
144. El-Enshasy, H.; Kleine, J.; Rinas, U. Agitation effects on morphology and protein productive fractions of filamentous and pelleted growth forms of recombinant Aspergillus niger. Process Biochem. 2006, 41, 2103-2112. [CrossRef]

145. Eibes, G.M.; Lú-Chau, T.A.; Ruiz-Dueñas, F.J.; Feijoo, G.; Martínez, M.J.; Martínez, A.T.; Lema, J.M. Effect of culture temperature on the heterologous expression of Pleurotus eryngii versatile peroxidase in Aspergillus hosts. Bioprocess Biosyst. Eng. 2009, 32, 129-134. [CrossRef]

146. Amanullah, A.; Christensen, L.H.; Hansen, K.; Nienow, A.W.; Thomas, C.R. Dependence of morphology on agitation intensity in fed-batch cultures of Aspergillus oryzae and its implications for recombinant protein production. Biotechnol. Bioeng. 2002, 77, 815-826. [CrossRef]

147. Archer, D.B.; MacKenzie, D.A.; Ridout, M.J. Heterologous protein secretion by Aspergillus niger growing in submerged culture as dispersed or aggregated mycelia. Appl. Microbiol. Biotechnol. 1995, 44, 157-160. [CrossRef]

148. Driouch, H.; Sommer, B.; Wittmann, C. Morphology engineering of Aspergillus niger for improved enzyme production. Biotechnol. Bioeng. 2010, 105, 1058-1068. [CrossRef]

149. Driouch, H.; Hänsch, R.; Wucherpfennig, T.; Krull, R.; Wittmann, C. Improved enzyme production by bio-pellets of Aspergillus niger: Targeted morphology engineering using titanate microparticles. Biotechnol. Bioeng. 2012, 109, 462-471. [CrossRef] [PubMed]

(C) 2020 by the authors. Licensee MDPI, Basel, Switzerland. This article is an open access article distributed under the terms and conditions of the Creative Commons Attribution (CC BY) license (http://creativecommons.org/licenses/by/4.0/). 